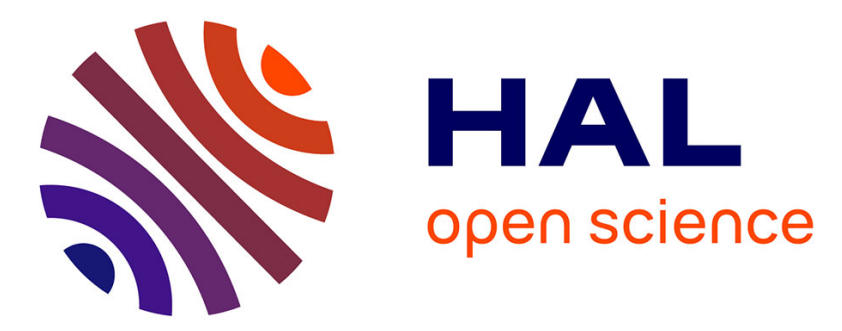

\title{
3D structure determination of amyloid fibrils using solid-state NMR spectroscopy
}

Antoine Loquet, Nadia El Mammeri, Stanek Jan, Mélanie Berbon, Benjamin Bardiaux, Guido Pintacuda, Birgit Habenstein

\section{To cite this version:}

Antoine Loquet, Nadia El Mammeri, Stanek Jan, Mélanie Berbon, Benjamin Bardiaux, et al.. 3D structure determination of amyloid fibrils using solid-state NMR spectroscopy. Methods, 2018, 138139, pp.26-38. 10.1016/j.ymeth.2018.03.014 . hal-01774854

\section{HAL Id: hal-01774854 \\ https://hal.science/hal-01774854}

Submitted on 24 Apr 2018

HAL is a multi-disciplinary open access archive for the deposit and dissemination of scientific research documents, whether they are published or not. The documents may come from teaching and research institutions in France or abroad, or from public or private research centers.
L'archive ouverte pluridisciplinaire HAL, est destinée au dépôt et à la diffusion de documents scientifiques de niveau recherche, publiés ou non, émanant des établissements d'enseignement et de recherche français ou étrangers, des laboratoires publics ou privés.

\section{(1) (1) $\$$}

Distributed under a Creative Commons Attribution - NonCommercial - NoDerivatives| 4.0 


\title{
3D Structure Determination of Amyloid Fibrils using Solid-State NMR Spectroscopy
}

\author{
Antoine Loquet ${ }^{1}$, Nadia El Mammeri ${ }^{1}$, Jan Stanek ${ }^{2}$, Mélanie Berbon ${ }^{1}$, Benjamin \\ Bardiaux $^{3}$, Guido Pintacuda ${ }^{2}$, Birgit Habenstein ${ }^{\text {* }}$ \\ ${ }^{1}$ Institute of Chemistry and Biology of Membranes and Nanoobjects, Institut Européen de Chimie et Biologie (CNRS UMR \\ 5248, Université de Bordeaux), 33600 Pessac, France. \\ ${ }^{2}$ Centre de RMN à Très Hauts Champs, Institut des Sciences Analytiques (CNRS, ENS Lyon, UCB Lyon 1), 69100 \\ Villeurbanne, France. \\ ${ }^{3}$ Unité de Bioinformatique Structurale, CNRS UMR 3528, Institut Pasteur, 75015 Paris, France. \\ Correspondance: b.habenstein@iecb.u-bordeaux.fr
}

\begin{abstract}
:
The amyloid fold is structurally characterized by a typical cross- $\beta$ architecture, which is under debate to represent an energy-favourable folding state that many globular or natively unfolded proteins can adopt. Being initially solely associated with amyloid fibrils observed in the propagation of several neurodegenerative disorders, the discovery of non-pathological (or "functional") amyloids in many native biological processes has recently further intensified the general interest invested in those cross- $\beta$ supramolecular assemblies. The insoluble and noncrystalline nature of amyloid fibrils and their usually inhomogeneous appearance on the mesoscopic level pose a challenge to biophysical techniques aiming at an atomic-level structural characterization. Solid-state NMR spectroscopy (SSNMR) has granted breakthroughs in structural investigations on amyloid fibrils ranging from the assessment of the impact of polymorphism in disease development to the 3D atomic structure determination of amyloid fibrils. First landmark studies towards the characterization of atomic structures and interactions involving functional amyloids have provided new impulses in the understanding of the role of the amyloid fold in native biological functions.

Over the last decade many strategies have been developed in protein isotope labelling, NMR resonance assignment, distance restraint determination and 3D structure calculation of amyloid fibrils based on SSNMR approaches. We will here discuss the emerging concepts and state-ofthe-art methods related to the assessment of amyloid structures and interactions involving amyloid entities by SSNMR.
\end{abstract}

Keywords:

Solid-state NMR, Amyloid fibrils, Structural biology, Protein aggregation, Prions, Structure calculation, Isotopic labelling, Proton detection

\section{Contents}

1. Introduction 2

2. Methods 3

2.1 SSNMR Sample preparation 3

2.1.1 Protein Production 3

2.1.2 Assembly and polymorphism 4

2.1.3 Isotope labeling 4

$\begin{array}{ll}2.2 \text { SSNMR analysis } & 6\end{array}$

2.2.1 SSNMR experiments for biomolecular assemblies $\quad 6$

2.2.2 Data analysis 6

2.2.3 Restraint detection and identification 7

2.2.4 1H-detection for investigation of amyloid structures $\quad 8$ 
2.3.2 Particularities of amyloid fibrils 9

2.3.3 Manual structure calculation 9

2.3.4 Automated structure calculation 10

3. Challenges and outlook

\section{Introduction}

The term amyloid is by definition suitable for any protein-based supramolecular assembly with congophilia (i.e. the propensity to bind the Congo red dye) and birefringence features, while displaying non-branched fibrils of approximately $10 \mathrm{~nm}$ in diameter [1]. The characterization of such unique entities has then been extended to the presence of the socalled cross- $\beta$ arrangement consisting in stacked $\beta$-strands perpendicular to the fibril axis that arrange as intermolecular $\beta$-sheets along the fibril axis (Fig.1A, B). This structural hallmark, presently considered to be a much more robust portrayal of the amyloid family, is adequately pictured through typical X-ray diffraction patterns [2, 3], in which are inferred some structural characteristics, as typical inter-strand and inter-sheet distances, respectively $4.7 \AA$ and $10 \AA$ (Fig.1C).

Interestingly, the physician Rudolph Virchow first introduced the word amyloid in 1854, while describing brain-related cellulose-like materials, called corpora amylacea [4]. It was later demonstrated that amyloid entities were in fact a novel class of proteins, which displays the ability to undergo conformational change and adopt the cross- $\beta$ architecture, thus forming amyloid fibrils. Such observations paved the way for ground-breaking discoveries in a multitude of research fields. This considerable attention fundamentally arises from their distinct association with a series of deadly (neuro-)degenerative disorders, called amyloidosis, such as Alzheimer's, Parkinson's diseases and type 2 diabetes [5-11].

There are to date 36 extracellular fibril proteins and 7 intracellular protein-based inclusions, with known disorder-related amyloid properties in humans [1]. Such amyloid assemblies are under thorough investigation in various fields of research, as the detailed understanding of their formation and the structural characteristics of the proteins with amyloid propensity could be the key to remedy the resulting disorders.

However, more recently it has become evident that the amyloid family can actually be split into two sub-classes, regarding their pathological or beneficial effects. These amyloids, executing native cellular functions, have been identified in a range of organisms from bacteria to mammals and are termed "functional amyloids" [12-18]. Hydrophobins, biofilm formation, hormone storage, cellular signal transduction or yeast prions are some of many examples illustrating the presence of amyloid-like systems involved in biological processes [19-26].

Such duality of effects, non-native aggregation and functional assembly, reveals the complexity of the amyloid fold. Several reports suggest that virtually any protein, when set in the proper conditions/environment, could adopt an amyloid-like $\beta$-strand-rich conformation, thus advocating the amyloid fold as a universal global free-energy minimum for polypeptide chains [27-29]. Nonetheless, the implication of functional amyloids in selective biological processes such as cellular signal transduction [20, 23-25] indicate that the recruitment strategies of amyloid monomers can be very specific and not necessary related to misfolding events.

As a consequence of the non-crystalline and insoluble character of amyloid fibrils, many obstacles impair the structure investigations at the atomic level of these systems based on well-established techniques such as X-ray crystallography or solution NMR spectroscopy. 
Additionally, a certain level of structural heterogeneity on the mesoscopic level often encountered in amyloid fibrils has hampered the use of cryo-electron microscopy (cryo-EM) until recently [30, 31]. Solid-state NMR (SSNMR) is a method of choice to achieve keen characterization of supramolecular assemblies in general [32-38], and more specifically of amyloid fibrillar assemblies at high resolution [39-42], as illustrated with the first structure determination of prion amyloid fibrils achieved in 2008 [43] by Meier and coworkers or with the discovery of the 3D fold of amyloid fibrils of $\alpha$-synuclein [44] and A $\beta$ [45-49], solved by SSNMR techniques. SSNMR capacity to probe the local order of "imperfect" inhomogeneous biological assemblies stands behind its power over amyloid fibrils [50]. High-resolution structures of amyloid proteins remain however extremely scarce, for only less than 10 amyloid fibril architectures have been described at high resolution (see Table 1).

To date, 110 protein/peptide 3D structures determined by SSNMR, including different types of protein complexes such as membrane-associated systems, macromolecular assemblies (filaments, fibrils, capsids), or microcrystalline proteins, have been deposited at the PDB (Protein Data Bank). Most high-resolution structures of amyloid fibrils have been elucidated using SSNMR as the main method: to date, 23 amyloid protein/peptide structures or structural models have been deposited in the PDB. Table 1 references all 23 structures (amongst which 3 synthetic constructs are found), and displays both the origin organism of the amyloid fibril, as well as the RMSD associated with the proposed structure/model. Figure 2 displays 5 of them.

This review endeavours to summarize and discuss methods and strategies that are used throughout the demanding task of determining the moderate- to high-resolution 3D structures of amyloid fibrils using SSNMR (Fig.2). While experimental data for virtually all deposited structures have been obtained using conventional ${ }^{13} \mathrm{C}$-detected SSNMR methods at moderate MAS frequencies, recent reports suggest that this class of samples can yield high resolution spectra also with ${ }^{1} \mathrm{H}$-detection at ultrafast MAS [51, 52]. The potential of this emerging method for collecting long-range distance restraints and ultimately for high-resolution structure determination has been recently demonstrated on microcrystalline model proteins and viral protein assemblies [53-60] and is yet to exploit to accelerate structural studies and increase accessible data for amyloid fibrils by significantly decreased commitment of material, laboratory and manpower resources.

\section{Methods}

\subsection{SSNMR Sample preparation}

\subsubsection{Protein Production}

Both chemical synthesis and production by recombinant expression in E. coli have been quite equally used in the above-mentioned structure determination processes (Table 1). Indeed most small protein/peptide samples (up to about 30-50 residues) are prepared based on well-known Fmoc-protection solid-phase chemical synthesis methods [61, 62], and HPLCbased purification. Higher molecular-weight proteins, however, are usually produced by $E$. coli-based recombinant expression followed by purification steps (Table 2). The latter protein production by heterologous expression has the advantage that isotope labeling $\left({ }^{2} \mathrm{H},{ }^{13} \mathrm{C},{ }^{15} \mathrm{~N}\right)$ can be easily implemented by introducing the labeled precursors in the bacterial expression medium. Furthermore, an arsenal of different selective labeling strategies based on heterologous expression have been developed and successfully applied to determine amyloid structures. During bacterial protein production, amyloid-forming proteins generally accumulate in inclusion bodies and need to be extracted (e.g. using $8 \mathrm{M}$ urea, or $6 \mathrm{M}$ guadinium chloride), followed by an enrichment and purification process, which could employ, one or several, affinity- and/or size-exclusion- and/or hydrophobic-chromatography procedures (Table 2). Note that the optimal protein expression conditions may vary between 
the production in rich, unlabeled and in poor bacterial expression medium that can be supplemented with labeled or unlabeled ${ }^{2} \mathrm{H},{ }^{13} \mathrm{C},{ }^{15} \mathrm{~N}$ sources. It is therefore beneficial in terms of cost and time effort to optimize the production in unlabeled poor medium before using isotope-labeled sources.

\subsubsection{Assembly and polymorphism}

Prior to actual NMR data recording and analysis, the polymerization process represents a significant step in the sample preparation because the conditions during the assembly play a major role in driving the protein subunits to adopt one specific homogeneous molecular structure, a heterogeneous variant or several structural polymorphs in the fibrillar sample. Incubation temperature and duration, $\mathrm{pH}$, protein concentration, nature of the buffer, presence/quantity of additional compounds (e.g. metal ions, chaotropic agents, chelating agents, redox reagents, antibacterial molecules, etc.), protein state upon rotor-packing (i.e. hydrated or lyophilized sample), are some of numerous conditions that need to be thoroughly optimized (Table 2) with both SSNMR and transmission electron microscopy as control tools. The optimization steps are crucial since conformational and structural differences in the fibril arrangement can be observed following only slight changes in sample preparation. Indeed, obtaining highly homogeneous samples is a compelling task in the field of SSNMR and the polymorph selection is often guided by the assembly conditions. The sample heterogeneity and polymorphism observed for amyloid fibrils is under constant discussion $[39,63,64]$, and polymorphism as well as fold instability might carry biological significance. Different structural polymorphs in disease-related amyloids lead to strains that might cause different clinical and pathological phenotypes [65-68] and that can vary in cellular toxicity [69-71].

SSNMR spectroscopy serves as a probe of the molecular-order at the atomic level, as it can detect slight differences in local conformational states in the assembly. Indeed, the level of sample homogeneity is directly reflected in the SSNMR line width and has thus a consequent impact on the structural analysis [40-42, 50]. The idea of using "seeds" during the assembly process has improved homogenizing the samples towards obtaining monomorphic species. As a matter of fact, amyloid fibrils are thought to assemble in a nucleationpolymerization manner, the first step being a slow reaction leading to the formation of the nucleus (described as the least stable intermediate) that can further react with more subunits to form a fibril in a favourable reaction [72]. This phenomenon can also explain the mechanism of infectious proteins such as prions. The slow nucleus formation can lead to a long lag phase, which can be bypassed by addition of preformed fibrils, referred to as "seeds". Amyloid fibrils seem to present a rather important stability (i.e. lack of polymorphism) when a certain length is reached, conveying the "seed" property [2, 73-75].

In a nucleation and assembly acceleration purpose, the use of assembly/sonication cycles has indeed been reported for many amyloid systems [47, 49, 76-79] (Table 2). One remarkable use of the "seed" property is the one of Tycko and co-workers who utilize brain extracts from deceased Alzheimer's patients, to obtain the structure of the disease-related A $\beta 40$ polymorph $[47,65]$.

\subsubsection{Isotope labeling}

SSNMR approaches require ${ }^{15} \mathrm{~N}$ and ${ }^{13} \mathrm{C}$ isotopic enrichment of biological samples to enhance abundance signal and allow site-specific studies. Protocols for amyloid sample preparation for SSNMR resemble those employed in solution NMR studies, but differ in that the final sample needs to be assembled from the monomeric subunits [38]. The development of isotopic labelling strategies has greatly enhanced the power of SSNMR in structural studies as the labelling schemes allow to selectively retrieve the desired information (i.e. a specific 
position of labelled ${ }^{13} \mathrm{C}$ and ${ }^{15} \mathrm{~N}$ nuclei within the amyloid proteins), to reduce dipolar truncation by spin dilution (distribution of labelled ${ }^{13} \mathrm{C}$ sites based on metabolic pathways of the used precursor), and to alleviate spectral congestion [80-83].

${ }^{13} \mathrm{C}-{ }^{15} \mathrm{~N}$ enrichment can either derive from chemically labelled precursors during solidphase chemical synthesis, for which the limitations in labelling combination are of chemical nature, or from the carbon sources that are used during recombinant expression. During Recombinant protein production metabolic pathways of the host introduce the ${ }^{13} \mathrm{C}$-labeling to specific positions in the amino acids [81]. Numerous selective ${ }^{13} \mathrm{C}$-labeling strategies have been exploited for SSNMR, such as using $\left[\mathrm{U}_{-}{ }^{13} \mathrm{C}\right]-,\left[1-{ }^{13} \mathrm{C}\right]-,\left[2-{ }^{13} \mathrm{C}\right]-,\left[1,3-{ }^{13} \mathrm{C}_{2}\right]-$ glucose or glycerol derivatives. These labelling systems can be used either for intra-molecular or intermolecular interaction determination (Fig.3) (see subsection 2.2.3).

${ }^{1} \mathrm{H}$-detected ssNMR is an attractive alternative to ${ }^{13} \mathrm{C}$-detected methods, which could in perspective alleviate the need for isotopic enrichment. However, ${ }^{1} \mathrm{H}$-detected SSNMR methods at moderate to fast MAS (approx. $20-60 \mathrm{kHz}$ ) need to be coupled not only to ${ }^{13} \mathrm{C}$ and ${ }^{15} \mathrm{~N}$-labelling to increase the separation of resonances in multidimensional spectra, but also to different levels of deuteration to ensure narrow linewidths in the ${ }^{1} \mathrm{H}$ dimension and sensitivity of detection. For example, extreme levels of proton dilution in side-chains are obtained by the expression in $\mathrm{D}_{2} \mathrm{O} / \mathrm{H}_{2} \mathrm{O}$ mixtures (e.g. the ratio of $9: 1$ ) and the use of ${ }^{2} \mathrm{H},{ }^{13} \mathrm{C}$ glucose as the sole carbon source, followed by a purification in $\mathrm{D}_{2} \mathrm{O}[84,85]$. Alternatively, an excess of $\mathrm{D}_{2} \mathrm{O}$ can be used for the expression, and a mixture of $\mathrm{D}_{2} \mathrm{O} / \mathrm{H}_{2} \mathrm{O}$ can be used during the purification/assembly step to partially reintroduce only exchangeable amide protons [86, 87]. However, a high dilution of protons severely limits the probability of observing ${ }^{1} \mathrm{H}-{ }^{1} \mathrm{H}$ contacts [88], therefore either a full back-exchange (in $100 \% \mathrm{H}_{2} \mathrm{O}$ ) or a selective protonation in side-chains with a $100 \%$ occupancy (e.g. at methyl sites) has been proposed to record amide-amide [53, 55, 89], methyl-amide and methyl-methyl [54, 56, 57, $90,91]$ interproton distance restraints. The selective non-random protonation circumvents the ${ }^{13} \mathrm{C}$ resolution issues related to ${ }^{2} \mathrm{H}$-induced shifts, maximises sensitivity and resolution, and allows to record long-range contacts between well-defined few ${ }^{1} \mathrm{H}$ sites. However, the amount of potentially available structural information is also significantly reduced, which can impair the high-resolution structure determination (yet possible with automation for small model proteins [57], but not on a larger molecular scale if not supplemented by other long-range restraints $[92,93])$. Also, incomplete exchange of amide ${ }^{1} \mathrm{H}$ can severely hamper the spectral analysis by ${ }^{1} \mathrm{H}$-detected SSNMR methods, particularly if a protein lacks a refolding protocol $[58,87,94,95]$. With the advent of fast spinning MAS probes $(>60 \mathrm{kHz})$, intermediate approaches were proposed, yielding a significantly lower deuteration level in side chains (and in particular, a full occupancy at $\mathrm{H \alpha}$ sites), such as "inverse fractional deuteration" [95] where ${ }^{2} \mathrm{H},{ }^{13} \mathrm{C}$-glucose and $100 \% \mathrm{H}_{2} \mathrm{O}$ is used for expression, and either $\mathrm{D}_{2} \mathrm{O}$ or $\mathrm{H}_{2} \mathrm{O}$ at the purification step. Recently, Meier and co-workers employed partial (about 75\%) deuteration for ${ }^{1} \mathrm{H}$-detection of amyloid fibrils of HET-s(218-289) at $60 \mathrm{kHz}$ MAS, where a $\mathrm{H}_{2} \mathrm{O}: \mathrm{D}_{2} \mathrm{O}$ ratio of 1:3 was used for expression, and either pure $\mathrm{D}_{2} \mathrm{O}$ or $\mathrm{H}_{2} \mathrm{O}$ was used for washing the resulting fibrils [96]. While this approach favours resolution of ${ }^{1} \mathrm{H}^{\mathrm{N}}$ and ${ }^{1} \mathrm{H} \alpha$ resonances over occupancy of ${ }^{1} \mathrm{H} \alpha$ sites, the non-uniform ${ }^{2} \mathrm{H}$-induced shifts degrade resolution in the ${ }^{13} \mathrm{C}$ dimension or, for a given sample, cause systematic inconsistencies of ${ }^{13} \mathrm{C} \alpha$ and ${ }^{13} \mathrm{C} \beta$ shifts in different spectra (or in different regions of the same spectrum) [96]. A number of studies have recently demonstrated that in the ultrafast MAS regime $(100-111 \mathrm{kHz})$ a large set of ${ }^{1} \mathrm{H}-{ }^{1} \mathrm{H}$ restraints can be obtained for fully-protonated microcrystalline proteins, viral assemblies or membrane-embedded proteins, thus alleviating all issues related to deuteration [51, 58-60, 97]. A detailed investigation on ${ }^{1} \mathrm{H}$ linewidths showed that at $111 \mathrm{kHz}$ MAS a minor resolution gain is expected even with a high level of deuteration for microcrystalline proteins 
[98], while partial deuteration remains beneficial for more dynamic systems such as membrane proteins [99] or (amyloid) fibrils.

The distinction of inter- and intramolecular contacts in ${ }^{1} \mathrm{H}$-detected SSNMR remains a challenge for sensitivity reasons, and until now is possible with a (uniform) mixed labelling with ${ }^{15} \mathrm{~N}$ or ${ }^{13} \mathrm{C}$, or by deuterating one part of the assembly [100].

\subsection{SSNMR analysis}

\subsubsection{SSNMR experiments for biomolecular assemblies}

Solid-state NMR has emerged as the method of choice for investigation of insoluble non-crystalline biopolymers at atomic resolution. The method is mainly based on two tools to circumvent issues such as line broadening and low signal to noise ratios associated with ${ }^{13} \mathrm{C}$ and ${ }^{15} \mathrm{~N}$. (i) Proteins in solid state move very slowly, so that the spectral lines are broadened considerably compared to solution NMR spectra on soluble proteins, for which the isotropic motion averages out several anisotropic NMR interactions. The use of MAS (i.e. Magic Angle Spinning) [101] allows for the recovery of spectral resolution. Indeed, the sample is spun at the magic angle (i.e. $54.7^{\circ}$; this angle averaging out several anisotropic interactions that are orientation-dependent) relative to the magnetic field. Therefore, many line-broadening interactions, such as CSA, quadrupolar and dipolar interactions, are partially averaged out by the MAS, leading to significant line-narrowing and an increase in resolution and signal to noise ratio. (ii) Cross-polarization (CP) is a well-established SSNMR experiment used to increase sensitivity of ${ }^{13} \mathrm{C}$ and ${ }^{15} \mathrm{~N}$ detection. Indeed, SSNMR usually uses ${ }^{13} \mathrm{C}$ and ${ }^{15} \mathrm{~N}$ nuclei, with low gyromagnetic ratios, which necessitate long experimental times to provide suitable signal. CP allows magnetization to be transferred from ${ }^{1} \mathrm{H}$ (high gyromagnetic ratio) to heteroatoms $\left(\right.$ e.g. ${ }^{13} \mathrm{C}$ and $\left.15 \mathrm{~N}\right)$ that are dipolar-coupled to enhance the signal and decrease the experimental time. To date, mostly ${ }^{13} \mathrm{C}$-based structure elucidation strategies have been employed on amyloid fibrils, but ${ }^{1} \mathrm{H}$-detected ultra-fast MAS are increasingly reported for this kind of systems.

\subsubsection{Data analysis}

1D, 2D, and 3D SSNMR spectra of amyloid fibrils are usually firstly recorded based on ${ }^{13} \mathrm{C}-{ }^{13} \mathrm{C},{ }^{13} \mathrm{C}-{ }^{15} \mathrm{~N},{ }^{13} \mathrm{C}-{ }^{15} \mathrm{~N}-{ }^{13} \mathrm{C},{ }^{15} \mathrm{~N}-{ }^{13} \mathrm{C}-{ }^{13} \mathrm{C}$ or $\left({ }^{1} \mathrm{H}-\right){ }^{15} \mathrm{~N}-{ }^{1} \mathrm{H}$ correlations in the aim of assigning different resonances to the protein atoms, as chemical shift assignments are a prerequisite for extracting structural information using NMR spectroscopy. The level of complexity during the resonance assignment process typically depends on the diversity of the amino acid composition, the presence or absence of repetitive sequence motifs, the extent of undetectable residues (due to static or dynamic disorder), structural homogeneity in the sample, available SSNMR technology and methodology and also on the availability of other biophysical data. Assigned SSNMR resonances (mainly ${ }^{13} \mathrm{C} \alpha,{ }^{13} \mathrm{C} \beta$ ) allow the secondary structure determination of all detected residues, based on the use of secondary chemical shifts [102].

When aiming at robust and high-resolution analysis, spectral crowdedness can hamper peak observation, and thus the 3D structural information collection, which is achieved by measuring inter- and intra-molecular distance restraints, obtained using polarization transfers between two atoms (usually ${ }^{1} \mathrm{H},{ }^{13} \mathrm{C}$, or ${ }^{15} \mathrm{~N}$ ), located below $\sim 2-10 \AA$ in space. Spin dilution, achieved through the above-mentioned labelling strategies $\left(\right.$ i.e. ${ }^{13} \mathrm{C}$-glucose and ${ }^{13} \mathrm{C}$-glycerolderived precursors) offers higher spectral resolution by reducing scalar one-bond ${ }^{13} \mathrm{C}-{ }^{13} \mathrm{C}$ couplings. In addition, the ${ }^{13} \mathrm{C}$ spin dilution improves the efficiency of polarization transfer between through-space coupled ${ }^{13} \mathrm{C}-{ }^{13} \mathrm{C}$ pairs, by decreasing the phenomenon of dipolar truncation $[103-105] \cdot\left[1-{ }^{13} \mathrm{C}\right]-,\left[2-{ }^{13} \mathrm{C}\right]-,\left[1,3-{ }^{13} \mathrm{C}_{2}\right]$ - glucose (or glycerol) labelling strategies allow the almost complete removal of one-bond dipolar, and J-couplings, thus considerably 
improving the spectral resolution, by a factor of $\sim 2$ or larger [36, 82, 106, 107]. Indeed, the reduced number of ${ }^{13} \mathrm{C}$-labeled sites lessens the spectral overlap, and permits the sequential assignment of short- and medium-range correlations. Many labelling combination have been developed over the years, in order to improve the data quality, and to target specific structural details. Both intra- and inter-molecular restraints are gathered prior to model calculations as described below.

\subsubsection{Restraint detection and identification}

For ${ }^{13} \mathrm{C} /{ }^{15} \mathrm{~N}$ based restraint identification several labelling and monomer-interaction combinations can be useful (Fig.3): (i) mix between ${ }^{13} \mathrm{C}$-labeled (or ${ }^{13} \mathrm{C}-{ }^{15} \mathrm{~N}$ ) and naturalabundance proteins for intra-molecular contacts [106] only (from 1:1 to 1:4 molar ratios) (Fig.3A); (ii) mix between two different labelling schemes (usually contains $50 \%$ of $\mathrm{U}_{-}{ }^{15} \mathrm{~N}$ with either $50 \%$ of $\left[\mathrm{U}_{-}{ }^{13} \mathrm{C}\right]$-glucose $[108],\left[2-{ }^{13} \mathrm{C}\right]$-, or $\left[1,3-{ }^{13} \mathrm{C}_{2}\right]$-glucose [107] or glycerol [109]) for inter-molecular contacts only (usually 1:1 molar ratio) (Fig.3B); (iii) [U- $\left.{ }^{13} \mathrm{C}\right]-$ glucose, $\left[2-{ }^{13} \mathrm{C}\right]$-, or $\left[1,3-{ }^{13} \mathrm{C}_{2}\right]$-glycerol residue labelling for all types of through-space contact detection (Fig.3C), based on 2D and 3D spectroscopy $[110,111]$.

The specific 1:1 $\left[1-{ }^{13} \mathrm{C}\right]$-glucose / $\left[2-{ }^{13} \mathrm{C}\right]$-glucose mix has been employed, for the measurement of definite intermolecular long-range distances [110, 112]. Furthermore, using a 1:1 U- ${ }^{15} \mathrm{~N} / \mathrm{U}-{ }^{13} \mathrm{C}$ mixed labelling scheme can reveal the amyloid fibril register, by comparing a NCA experiment (usually displaying the backbone correlation ${ }^{15} \mathrm{~N} /{ }^{13} \mathrm{C} \alpha$ of a residue) of a U${ }^{13} \mathrm{C}-{ }^{15} \mathrm{~N}$ sample and the one of the $1: 1 \mathrm{U}-{ }^{15} \mathrm{~N} / \mathrm{U}_{-}{ }^{13} \mathrm{C}$ mix. Indeed, an in-register stacking will show perfect overlap of the two experiments, and the ${ }^{13} \mathrm{C} \alpha$ of a residue $\mathrm{i}$ will be in direct contact with the backbone ${ }^{15} \mathrm{~N}$ labelling of the same residue on the adjacent monomer, thus showing the same ${ }^{15} \mathrm{~N} /{ }^{13} \mathrm{C} \alpha$ correlations as the one observed in a uniformly ${ }^{13} \mathrm{C}-{ }^{15} \mathrm{~N}$ labelled sample. Generally, most long-range through-space correlations will appear on the $\left[2-{ }^{13} \mathrm{C}\right]-$ glycerol and $\left[1,3-{ }^{13} \mathrm{C}_{2}\right]$-glycerol samples, and the same labelling scheme diluted in naturalabundance monomers (i.e. mixed prior to assembly) should suffice to discriminate inter- from intra-molecular residue contacts (Fig.3); the applied molar ratio between labelled and unlabelled monomers should reflect a compromise, to prevent both ${ }^{13} \mathrm{C}-{ }^{13} \mathrm{C}$ inter-molecular correlations and data with too low signal (e.g. having only $\sim 50 \%$ of the sites ${ }^{13} \mathrm{C}$-labeled in the amyloid fibrils will reduce the signal to noise ratio by $\sim 4$ ).

The ${ }^{13} \mathrm{C}-{ }^{13} \mathrm{C}$ correlations, displayed as peaks on the spectra, are usually considered as four different types of contacts: (i) intra-residual ${ }^{13} \mathrm{C}-{ }^{13} \mathrm{C}$ correlations, which account for ${ }^{13} \mathrm{C}$ labeled sites of the same residue; (ii) short-range correlations, which comprise inter-residual interactions (between a residue $i$ and the residues $i+1$ and $i+2$ ) (also referred to as "sequential correlations"); (iii) medium-range correlations include the correlations from $\mathrm{i}+2$ to $\mathrm{i}+4$; (iv) long-range ${ }^{13} \mathrm{C}-{ }^{13} \mathrm{C}$ correlations contain $\mathrm{i}$ to $>\mathrm{i}+4$ contacts, crucial for determining long-range through-space restraints further used during structure calculations. Indeed, in optimal conditions (e.g. high spectral resolution, high signal to noise ratios, no polymorphism, etc.) a complete and thorough analysis of the SSNMR data should provide a list of ${ }^{13} \mathrm{C}^{13} \mathrm{C}$ longrange correlations subdivided into four groups: unambiguous inter-molecular, ambiguous inter-molecular, unambiguous intra-molecular, and ambiguous intra-molecular distances; both the quantity and quality of restraints are to be considered. Figure 4 illustrates such data set with the example of HET-s fibrils [43], in which reported distances involving T233 and I231 are displayed.

Interestingly, the 3D structure model construction of amyloid fibrils often requires hybrid approaches, which employ data acquired using other techniques, such as X-ray diffraction to determine the cross-beta signature, or scanning transmission electron microscopy (STEM), which give information about the mass-per-unit-lengths parameters [33, $45,113,114]$. From such analysis, a data set, comprising knowledge about the molecular 
atomic structure from SSNMR experiment and fibril morphology with STEM analysis, will be the basis for the complex model calculation and energy minimization processes.

\subsection{4 ${ }^{1}$ H-detection for investigation of amyloid structures}

${ }^{1} \mathrm{H}$ detection boosts sensitivity and allows the direct observation of ${ }^{1} \mathrm{H}-{ }^{1} \mathrm{H}$ proximities. ${ }^{1} \mathrm{H}-{ }^{1} \mathrm{H}$ proximities represent natural restraints for structure calculation, easy to interpret, and in contrast to ${ }^{13} \mathrm{C}-{ }^{13} \mathrm{C}$ interactions, are a direct indication of physical close contacts, especially relevant across beta-strands or within hydrophobic patches.

The capabilities of ${ }^{1} \mathrm{H}$-detected techniques with respect to a full structure determination in the solid state have been demonstrated in a number of microcrystalline systems [53-57, 115]. MAS rates in the 40-60 kHz range were employed, aided by extensive sample deuteration and selective reintroduction of protons (see section 2.1), allowing a significant reduction in the sample amount required, as well as faster spectral acquisition and unbiased automated data analysis. The approach has recently been extended toward the determination of a membraneembedded target, in combination with ${ }^{13} \mathrm{C}-{ }^{13} \mathrm{C}$ constraints $[89,91]$.

While no structure of an amyloid fiber has yet been determined solely from ${ }^{1} \mathrm{H}$-detected SSNMR data, a growing number of studies has demonstrated the feasibility of these techniques in this context. Notably, this approach considerably accelerates resonance assignment, which represent the first but crucial phase of a NMR structure determination and provides a quick evidence of the secondary structure adopted by the protein.

In a pioneering study, Reif and coworkers demonstrated high-resolution ${ }^{1} \mathrm{H}$-detected spectra for Alzheimer disease $\beta$-amyloid peptide $\mathrm{A} \beta$ (1-40), using $20 \mathrm{kHz}$ MAS and a deuterated sample back-reprotonated at the amide sites at $25-50 \%$ [87]. There, $2 \mathrm{D}-{ }^{1} \mathrm{H},{ }^{15} \mathrm{~N}$ fingerprint correlation spectra were used as a clear and rapid readout of sample homogeneity, enabling the optimization of fiber preparation through multiple seeding cycles. Recently, Meier and coworkers showed that ${ }^{1} \mathrm{Ha},{ }^{15} \mathrm{~N},{ }^{13} \mathrm{Ca}$ inter-residue correlations can be used to transfer available ${ }^{13} \mathrm{C}$ and ${ }^{15} \mathrm{~N}$ assignments to $\alpha$-protons in a partially (above $75 \%$ ) deuterated sample of HET-s(218-289) at $60 \mathrm{kHz}$ MAS [96].

The use of MAS rates beyond $100 \mathrm{kHz}$ allows to extend the approach and removes the requirement of proton dilution by deuteration, opening the way to the sensitive detection of amide and aliphatic protons in fully protonated proteins. In particular, a set of experiment was proposed for sequence-specific backbone and aliphatic side-chain resonance assignments and demonstrated on HET-s(218-289) fibrils. Only $500 \mu \mathrm{g}$ of sample and few days of data acquisition were used in this study [51]. Overall, this opens the perspective of determining tertiary and quaternary structures of amyloids by directly probing side-chain-to-side-chain and/or backbone-to-side-chain ${ }^{1} \mathrm{H}-{ }^{1} \mathrm{H}$ proximities [58].

\subsection{Structure calculation}

Despite their topological peculiarities, high-resolution 3D structures of amyloid fibrils can be determined from SSNMR data using the same general procedure as for solution NMR, i.e.: (i) conversion of assigned NMR observables into structurally meaningful restraints, (ii) calculation of hundreds of conformers by restrained molecular-dynamics simulation and (iii) selection of best fitting conformers as final structure bundle.

\subsubsection{Restraints collection}

Detected cross-peak signals in relevant hetero- or homo-nuclear spectra are first converted into restraints restricting the distance between the different assigned nuclei. In solid-state NMR studies, distance restraints often take the form of an upper-bound distance that can be either estimated from peak intensity and known reference distances or from L-shape curves 
obtained from multiple structure calculation trials with increasing upper-limits [116]. It is worth noting that the success of structure calculation strongly relies on a critical number of long-range (between residues separated by more than 5 residues in sequence) and intermolecular restraints (between different subunits).

The restraint set for structure calculation can be supplemented by dihedral angle restraints on $\varphi / \Psi$ backbone angles, predicted from backbone secondary chemical shifts using tools like TALOS + [117]. Additionally, the stacking of subunits can be maintained during structure calculation with backbone hydrogen-bond restraints between paired strands in neighboring subunits stacked along the fibril axis. These restraints typically impose upper limit distances between donor $(\mathrm{N})$ and acceptor $(\mathrm{O})$, and amide hydrogen $(\mathrm{HN})$ and acceptor of $3.0 \AA$ and 2.0 $\AA$, respectively. When the hydrogen-bonding pattern (parallel/anti-parallel, register) is not unambiguously established, multiple structural calculation with various hydrogen-bonding possibilities can be tested in parallel and the most favorable solution (lowest target function or smallest number of restraint violations) selected for analysis [45, 118]. On the basis on the collected restraints, several conformers (usually hundreds) are then calculated using dedicated software, such as CYANA [119], UNIO [120], ARIA [121], XPLOR-NIH [122] or Rosetta [123] that perform restrained molecular modeling.

\subsubsection{Particularities of amyloid fibrils}

Since amyloid fibrils are assemblies of repeated monomeric subunits arranged in stacked layers (protofibril), it is necessary to model them as such by including multiple copies of the subunits ( 3 to 5 layers along the fibril axis). If mass-per-length measurements or other approaches provide evidences for the presence of multiple subunits in a single layer [47, 77, $118,124]$, interfacial contacts between protofibrils must be also explicitly modeled by incorporating the required number of subunit copies per layer. Amyloid fibrils are quasi-onedimensional system, where a homogenous core region give rise to a single set of resonances, indicating that all subunits are in the same molecular conformations and organized in a symmetric manner. During structure calculation, this symmetry must be enforced through the application of three symmetry terms (Fig.5): (i) identity restraints that minimize either atomic root mean square deviation (RMSD) using non-crystallographic symmetry restraints (NCS) [125] or torsion angles difference between all subunits [126], (ii) axial stacking restraints minimizing intermolecular distance differences between equivalent pairs of atoms (typically $\mathrm{C} \alpha$ ) in neighboring subunits [125] and (iii) interfacial symmetry maintaining the proper rotational symmetric with the same principle of axial stacking (distance difference) but between subunit in the same layer. Ideally, symmetry of fibrils can be entirely described by the atomic coordinates of a single subunit and appropriate symmetry operators to reconstruct the structure of the neighbors. While such an approach has been successfully applied with ARIA for structure determination of helical fibers by SSNMR [127], its extension to amyloid fibrils remains challenging since the required symmetry information (mainly the rotational twist between neighboring subunits around the fibrils axis) are difficult to obtain with sufficient accuracy.

\subsubsection{Manual structure calculation}

Direct application of automated NMR cross-peak assignment and structure calculation tools used routinely for solution NMR data is pragmatically limited for amyloid fibrils due to not only the lower spectral resolution of SSNMR but also the difficulty to disentangle intra- and inter-molecular restraints, the latter potentially originating from axial (along the fibril axis) or lateral (between protofibrils) contacts. It is thus common practice to first perform structure calculation using solely SSNMR restraints that could be assigned unambiguously or with very limited spectra ambiguity that can be identified manually by a trained operator (ca. few 
dozens of long-range and a handful of inter-molecular restraints at least). Such manual structure calculation (Fig.5) generally determines an initial fold with reasonable precision that will serve to identified new compatible restraints for additional rounds of manual calculation. At this stage, it is important to carefully replicate restraints for all equivalent subunits to respect the symmetric nature of the fibrils.

\subsubsection{Automated structure calculation}

Alternatively, one can proceed with automated structure calculation (Fig.5) using all remaining cross-peaks for which unambiguous assignment cannot be safely obtained manually. For instance, the CYANA software can assist in automatically collecting assignment possibilities by matching cross-peaks positions with the list of assigned chemical shifts according to user defined tolerance windows. These tolerances for assignment of crosssignals should be reflective of the linewidth in the different dimensions of the originating spectrum. CYANA then carries out an iterative protocol by alternating calculation of conformer bundles and selection of the most probable assignments compatible with the structures, hence reducing human bias in assigning cross-peaks. As a consequence of the increased number of restraints used, more precise structure bundled are obtained (bundle RMSD for backbone $<1 \AA$ ). The reliability of the automated calculation should be assessed by monitoring the bundle RMSD in early cycles of calculation (RMSD for backbone $<3 \AA$ ) and the number of discarded restraints, especially long-range; restraint violations in the final bundle should be as low as possible.

Finally, structure of amyloid fibrils should be validated with standard validation tools such as PROCHECK [128] or MolProbity [129] prior to deposition in the Protein Data Bank [130]. Examples of amyloid fibrils structures determined by SSNMR are shown in Figure 2.

\section{Challenges and outlook}

Solid-state NMR spectroscopy plays an important role throughout the challenging task of understanding the functional mechanisms of amyloid proteins, the molecular basis of misfolding events, and protein aggregation in general [32, 131]. Essential improvements achieved in SSNMR instrumentation (e.g. ultra-fast MAS NMR probes, pulse sequences), dedicated NMR-based structure calculation software development, protein sample preparation techniques, and isotope labelling-schemes have led to breakthroughs and advancements in many structural inquiries in the field of amyloid proteins, and other types of supramolecular assemblies. Focus is now on further applications, technological developments and progress of the technique to speed up the structural studies on amyloid proteins by SSNMR since the number of known pathological and non-pathological amyloid fibrils continuously increases, and the specific and accurate roles of amyloid fibrils in many biological processes still remains elusive.

Protein aggregation is implicated in many misfolding diseases including Alzheimer's disease and type-2 diabetes. Recent studies have shown that the aggregation process is toxic to cells but the end product fibrils need not be the most-toxic species [132, 133]. Nevertheless, such extensive structural characterization of amyloid proteins in their assembled state could be the key to unravel the molecular mechanisms at the atomic level in diseases and in cellular processes, and to consequently develop drugs/chemicals specifically targeting the amyloid proteins. Furthermore, SSNMR applications increasingly target not only the end products, i.e. mature fibrils, but also the on- and off-pathway formed oligomers or "protofibers". The potential of SSNMR to characterize also these smaller and often less stables protein complexes is rapidly evolving [132-145], and might benefit even more to drug conception. Finally, atomic-level structural studies of amyloid fibrils also provide valuable insights for designing self-assembling biomaterials. 
Although the majority of the structural investigations discussed in the present review rely on ${ }^{13} \mathrm{C}$-detected methods, ${ }^{1} \mathrm{H}$-detection schemes have recently attracted growing attention due to a leap forward in the MAS instrumentation. ${ }^{1} \mathrm{H}$-detected approaches based on $>100 \mathrm{kHz}$ MAS enable nowadays a boost in sensitivity through the full exploitation of the ${ }^{1} \mathrm{H}$ high gyromagnetic ratio and high abundance in fully-protonated samples. It remains to be demonstrated how ${ }^{1} \mathrm{H}$-detection can impact more generally on amyloid structural studies because amyloids are frequently prone to slight structural variations inflicting structural inhomogeneity and/or polymorphism and therefore heterogeneous line-broadening, which might be more limiting to the resolution in the ${ }^{1} \mathrm{H}$-dimension than it is in ${ }^{13} \mathrm{C}$. However, the advances in ${ }^{1} \mathrm{H}$-detection methodology have drastically enhanced the efficacy of SSNMR in protein structural studies [51, 58, 97, 98, 146], and are now expected to pave the way for further remarkable amyloid structural and dynamic investigations.

\section{Acknowledgments:}

We acknowledge financial support from the European Research Council (ERC) under the European Unions Horizon 2020 research and innovation programme (ERC-2015-StG GA no. 639020 to A.L. and ERC-2015-CoG GA no. 648974 to G.P.), the European Commission's REA with a Marie Sklodowska-Curie fellowship (GA 661799) to J.S., IdEx Bordeaux (Chaire d'Installation to B.H., ANR-10-IDEX-03-02), the ANR (ANR-14-CE09-0020-01 to A.L., ANR-13-PDOC-0017-01 to B.H.).

\section{References}

1. Sipe, J.D., et al., Amyloid fibril proteins and amyloidosis: chemical identification and clinical classification International Society of Amyloidosis 2016 Nomenclature Guidelines. Amyloid, 2016. 23(4): p. 209-213.

2. Eichner, T. and S.E. Radford, $A$ diversity of assembly mechanisms of a generic amyloid fold. Molecular Cell, 2011.43(1): p. 8-18.

3. Sunde, M., et al., Common core structure of amyloid fibrils by synchrotron $X$-ray diffraction. Journal of Molecular Biology, 1997. 273(3): p. 729-739.

4. Sipe, J.D. and A.S. Cohen, Review: history of the amyloid fibril. Journal of Structural Biology, 2000. 130(2-3): p. 88-98.

5. Eisenberg, D. and M. Jucker, The amyloid state of proteins in human diseases. Cell, 2012. 148(6): p. 1188-203.

6. Knowles, T.P., M. Vendruscolo, and C.M. Dobson, The amyloid state and its association with protein misfolding diseases. Nature Reviews Molecualr Cell Biology, 2014. 15(1471-0080 (Electronic)): p. 384-396.

7. Eisele, Y.S., et al., Targeting protein aggregation for the treatment of degenerative diseases. Nature Reviews Drug Discovery, 2015. 14(11): p. 759-80.

8. Selkoe, D.J. and J. Hardy, The amyloid hypothesis of Alzheimer's disease at 25 years. EMBO Molecular Medicine, 2016. 8(6): p. 595-608.

9. Kotler, S.A., et al., Differences between amyloid-[small beta] aggregation in solution and on the membrane: insights into elucidation of the mechanistic details of Alzheimer's disease. Chemical Society Reviews, 2014. 43(19): p. 6692-6700.

10. Patel, H.R., et al., In Search of Aggregation Pathways of IAPP and Other Amyloidogenic Proteins: Finding Answers through NMR Spectroscopy. The Journal of Physical Chemistry Letters, 2014. 5(11): p. 1864-1870.

11. Brender, J.R., S. Salamekh, and A. Ramamoorthy, Membrane Disruption and Early Events in the Aggregation of the Diabetes Related Peptide IAPP from a Molecular Perspective. Accounts of Chemical Research, 2012. 45(3): p. 454-462.

12. Romero, D. and R. Kolter, Functional amyloids in bacteria. International Microbiology, 2014. 17(2): p. 65-73.

13. Pham, C.L., A.H. Kwan, and M. Sunde, Functional amyloid: widespread in Nature, diverse in purpose. Essays in Biochemistry, 2014. 56: p. 207-19. 
14. Otzen, D., Functional amyloid: turning swords into plowshares. Prion, 2010. 4(4): p. 256-64.

15. Maury, C.P., The emerging concept of functional amyloid. Journal of Internal Medicine, 2009. 265(3): p. 329-34.

16. Fowler, D.M., et al., Functional amyloid--from bacteria to humans. Trends in Biochemical Sciences, 2007. 32(5): p. 217-24.

17. Fowler, D.M., et al., Functional amyloid formation within mammalian tissue. PLoS Biology, 2006. 4(1): p. e6.

18. Riek, R. and D.S. Eisenberg, The activities of amyloids from a structural perspective. Nature, 2016. 539(7628): p. 227-235.

19. Macedo, B., et al., Mammalian prion protein (PrP) forms conformationally different amyloid intracellular aggregates in bacteria. Microbial Cell Factories, 2015. 14: p. 174.

20. Li, J., et al., The RIP1/RIP3 necrosome forms a functional amyloid signaling complex required for programmed necrosis. Cell, 2012. 150(2): p. 339-50.

21. Di Martino, P., Bap: A New Type of Functional Amyloid. Trends in Microbiology, 2016. 24(9): p. 682-4.

22. Maji, S.K., et al., Functional Amyloids As Natural Storage of Peptide Hormones in Pituitary Secretory Granules. Science, 2009. 325: p. 328-332.

23. Daskalov, A., et al., Identification of a novel cell death-inducing domain reveals that fungal amyloid-controlled programmed cell death is related to necroptosis. Proceedings of the National Academy of Sciences, 2016. 113(10): p. 2720-5.

24. Daskalov, A., et al., Signal transduction by a fungal NOD-like receptor based on propagation of a prion amyloid fold. PLoS Biology, 2015. 13(2): p. e1002059.

25. Saupe, S. and A. Daskalov, The [Het-s] Prion, an Amyloid Fold as a Cell Death Activation Trigger. PloS Pathogens, 2012.8(5).

26. Hartman, K., et al., Bacterial curli protein promotes the conversion of PAP(248-286) into the amyloid SEVI: cross-seeding of dissimilar amyloid sequences. PeerJ, 2013. 1: p. e5.

27. Chiti, F., et al., Designing conditions for in vitro formation of amyloid protofilaments and fibrils. Proceedings of the National Academy of Sciences, 1999. 96(7): p. 35903594.

28. Dobson, C.M., Protein folding and misfolding. Nature, 2003. 426: p. 884.

29. Guijarro, J.I., et al., Amyloid fibril formation by an SH3 domain. Proceedings of the National Academy of Sciences, 1998. 95(8): p. 4224-4228.

30. Fitzpatrick, A.W.P., et al., Cryo-EM structures of tau filaments from Alzheimer's disease. Nature, 2017. 547(7662): p. 185-190.

31. Gremer, L., et al., Fibril structure of amyloid- $\beta(1-42)$ by cryo-electron microscopy. Science, 2017. 358(6359): p. 116-119.

32. Linser, R., Solid-state NMR spectroscopic trends for supramolecular assemblies and protein aggregates. Solid State Nuclear Magnetic Resonance, 2017. 87: p. 45-53.

33. Habenstein, B. and A. Loquet, Solid-state NMR: An emerging technique in structural biology of self-assemblies. Biophysical Chemistry, 2016. 210: p. 14-26.

34. Sun, S., et al., Solid-state NMR spectroscopy of protein complexes. Methods in Molecular Biology, 2012. 831: p. 303-31.

35. Weingarth, M. and M. Baldus, Solid-state NMR-based approaches for supramolecular structure elucidation. Accounts Of Chemical Research, 2013. 46(9): p. 2037-2046.

36. Loquet, A., B. Habenstein, and A. Lange, Structural Investigations of Molecular Machines by Solid-State NMR. Accounts Of Chemical Research, 2013. 46(9): p. 2070-2079.

37. Andreas, L.B., et al., High-resolution proton-detected NMR of proteins at very fast MAS. Journal of Magnetic Resonance, 2015. 253: p. 36-49.

38. Loquet, A., et al., Atomic Scale Structural Studies of Macromolecular Assemblies by Solid-state Nuclear Magnetic Resonance Spectroscopy. Journal of Visualized Experiments, 2017(127): p. e55779.

39. Tycko, R. and R.B. Wickner, Molecular structures of amyloid and prion fibrils: consensus versus controversy. Accounts Of Chemical Research, 2013.46(7): p. 148796. 
40. Tycko, R., Solid-state NMR studies of amyloid fibril structure. Annual Review of Physical Chemistry, 2011. 62: p. 279-99.

41. Meier, B.H. and A. Böckmann, The structure of fibrils from 'misfolded' proteins. Current Opinion in Structural Biology, 2015. 30: p. 43-9.

42. Comellas, G. and C.M. Rienstra, Protein structure determination by magic-angle spinning solid-state NMR, and insights into the formation, structure, and stability of amyloid fibrils. Annual Review of Biophysics, 2013. 42: p. 515-36.

43. Wasmer, C., et al., Amyloid fibrils of the HET-s(218-289) prion form a beta solenoid with a triangular hydrophobic core. Science, 2008. 319(5869): p. 1523-6.

44. Tuttle, M.D., et al., Solid-state NMR structure of a pathogenic fibril of full-length human alpha-synuclein. Nature Structural \& Molecular Biology, 2016. 23(5): p. 40915.

45. Walti, M.A., et al., Atomic-resolution structure of a disease-relevant Abeta(1-42) amyloid fibril. Proceedings of the National Academy of Sciences, 2016. 113(34): p. E4976-84.

46. Colvin, M.T., et al., Atomic Resolution Structure of Monomorphic Abeta42 Amyloid Fibrils. Journal of the American Chemical Society, 2016. 138(30): p. 9663-74.

47. Lu, J.X., et al., Molecular structure of beta-amyloid fibrils in Alzheimer's disease brain tissue. Cell, 2013. 154(6): p. 1257-68.

48. Petkova, A.T., et al., A structural model for Alzheimer's $\beta$-amyloid fibrils based on experimental constraints from solid state NMR. Proceedings of the National Academy of Sciences, 2002.99(26): p. 16742-16747.

49. Paravastu, A.K., et al., Molecular structural basis for polymorphism in Alzheimer's beta-amyloid fibrils. Proceedings of the National Academy of Sciences, 2008. 105(47): p. 18349-18354.

50. Meier, B.H., R. Riek, and A. Bockmann, Emerging Structural Understanding of Amyloid Fibrils by Solid-State NMR. Trends in Biochemical Sciences, 2017.

51. Stanek, J., et al., NMR Spectroscopic Assignment of Backbone and Side-Chain Protons in Fully Protonated Proteins: Microcrystals, Sedimented Assemblies, and Amyloid Fibrils. Angewandte Chemie International Edition, 2016. 55(50): p. 1550415509.

52. Zhang, R., K.H. Mroue, and A. Ramamoorthy, Proton-Based Ultrafast Magic Angle Spinning Solid-State NMR Spectroscopy. Accounts of Chemical Research, 2017. 50(4): p. 1105-1113.

53. Zhou, D.H., et al., Solid-State Protein Structure Determination with Proton-Detected Triple Resonance 3D Magic-Angle Spinning NMR Spectroscopy. Angewandte Chemie International Edition, 2007. 46(44): p. 8380-8383.

54. Huber, M., et al., A Proton-Detected 4D Solid-State NMR Experiment for Protein Structure Determination. ChemPhysChem, 2011. 12(5): p. 915-918.

55. Knight, M.J., et al., Fast Resonance Assignment and Fold Determination of Human Superoxide Dismutase by High-Resolution Proton-Detected Solid-State MAS NMR Spectroscopy. Angewandte Chemie International Edition, 2011. 50(49): p. 1169711701.

56. Linser, R., et al., Structure Calculation from Unambiguous Long-Range Amide and Methyl 1H-1H Distance Restraints for a Microcrystalline Protein with MAS SolidState NMR Spectroscopy. Journal of the American Chemical Society, 2011. 133(15): p. $5905-5912$.

57. Agarwal, V., et al., De Novo 3D Structure Determination from Sub-milligram Protein Samples by Solid-State $100 \mathrm{kHz} M A S$ NMR Spectroscopy. Angewandte Chemie International Edition, 2014. 53(45): p. 12253-12256.

58. Andreas, L.B., et al., Structure of fully protonated proteins by proton-detected magicangle spinning NMR. Proceedings of the National Academy of Sciences, 2016. 113(33): p. 9187-92.

59. Jain, M.G., et al., Selective 1H-1H Distance Restraints in Fully Protonated Proteins by Very Fast Magic-Angle Spinning Solid-State NMR. The Journal of Physical Chemistry Letters, 2017. 8(11): p. 2399-2405. 
60. Lalli, D., et al., Proton-Based Structural Analysis of a Heptahelical Transmembrane Protein in Lipid Bilayers. Journal of the American Chemical Society, 2017. 139(37): p. 13006-13012.

61. Raibaut, L., O. El Mahdi, and O. Melnyk, Solid Phase proteins Chemical Synthesis. Topics in Current Chemistry, 2015. 363: p. 103-154.

62. Guan, X., et al., New Methods for Chemical Protein Synthesis. Topics in Current Chemistry, 2015. 363: p. 155-192.

63. Tycko, R., Amyloid polymorphism: structural basis and neurobiological relevance. Neuron, 2015. 86(3): p. 632-45.

64. Eisenberg, D.S. and M.R. Sawaya, Structural Studies of Amyloid Proteins at the Molecular Level. Annual Review of Biochemistry, 2017. 86(1): p. 69-95.

65. Qiang, W., et al., Structural variation in amyloid- $\beta$ fibrils from Alzheimer's disease clinical subtypes. Nature, 2017. 541: p. 217.

66. Cohen, M.L., et al., Rapidly progressive Alzheimer's disease features distinct structures of amyloid- $\beta$. Brain, 2015. 138(4): p. 1009-1022.

67. Collinge, J. and A.R. Clarke, A General Model of Prion Strains and Their Pathogenicity. Science, 2007. 318(5852): p. 930-936.

68. Safar, J., et al., Eight prion strains have PrPSc molecules with different conformations. Nature Medicine, 1998. 4: p. 1157.

69. Petkova, A.T., et al., Self-Propagating, Molecular-Level Polymorphism in Alzheimer's B-Amyloid Fibrils. Science, 2005. 307(5707): p. 262-265.

70. Gath, J., et al., Unlike Twins: An NMR Comparison of Two $\alpha$-Synuclein Polymorphs Featuring Different Toxicity. PLoS One, 2014. 9(3): p. e90659.

71. Bousset, L., et al., Structural and functional characterization of two alpha-synuclein strains. Nature Communications, 2013. 4: p. 2575.

72. Westermark, G.T., et al., Noncerebral Amyloidoses: Aspects on Seeding, CrossSeeding, and Transmission. Cold Spring Harbor Perspectives in Medicine, 2018. 8(1).

73. Baxa, U., Structural basis of infectious and non-infectious amyloids. Current Alzheimer Research, 2008. 5: p. 308-318.

74. Sabate, R., et al., Prion and non-prion amyloids of the HET-s prion forming domain. Journal of Molecular Biology, 2007. 370(4): p. 768-83.

75. Baxa, U., et al., Structure, Function, and Amyloidogenesis of Fungal Prions: Filament Polymorphism and Prion Variants. Advances in Protein Chemistry, 2006. 73: p. 125180.

76. Xiao, Y., et al., Abeta(1-42) fibril structure illuminates self-recognition and replication of amyloid in Alzheimer's disease. Nature Structural \& Molecular Biology, 2015. 22(6): p. 499-505.

77. Sgourakis, N.G., W.M. Yau, and W. Qiang, Modeling an in-register, parallel "iowa" abeta fibril structure using solid-state NMR data from labeled samples with rosetta. Structure, 2015. 23(1): p. 216-27.

78. Qiang, W., et al., Antiparallel beta-sheet architecture in Iowa-mutant beta-amyloid fibrils. Proceedings of the National Academy of Sciences, 2012. 109(12): p. 4443-8.

79. Ferguson, N., et al., General structural motifs of amyloid protofilaments. Proceedings of the National Academy of Sciences, 2006. 103(44): p. 16248-16253.

80. Lacabanne, D., B.H. Meier, and A. Böckmann, Selective labeling and unlabeling strategies in protein solid-state NMR spectroscopy. Journal of Biomolecular NMR, 2017.

81. Higman, V.A., et al., Assigning large proteins in the solid state: a MAS NMR resonance assignment strategy using selectively and extensively 13C-labelled proteins. Journal of Biomolecular NMR, 2009. 44(4): p. 245-60.

82. Hong, M., Determination of Multiple $\phi$-Torsion Angles in Proteins by Selective and Extensive 13C Labeling and Two-Dimensional Solid-State NMR. Journal of Magnetic Resonance, 1999. 139(2): p. 389-401.

83. Lundstrom, P., et al., Fractional 13C enrichment of isolated carbons using [1-13C]- or [2- 13C]-glucose facilitates the accurate measurement of dynamics at backbone Calpha and side-chain methyl positions in proteins. Journal of Biomolecular NMR, 2007. 38(3): p. 199-212. 
84. Paulson, E.K., et al., Sensitive High Resolution Inverse Detection NMR Spectroscopy of Proteins in the Solid State. Journal of the American Chemical Society, 2003. 125(51): p. 15831-15836.

85. Asami, S., P. Schmieder, and B. Reif, High Resolution 1H-Detected Solid-State NMR Spectroscopy of Protein Aliphatic Resonances: Access to Tertiary Structure Information. Journal of the American Chemical Society, 2010. 132(43): p. 1513315135 .

86. Chevelkov, V., et al., Ultrahigh Resolution in Proton Solid-State NMR Spectroscopy at High Levels of Deuteration. Angewandte Chemie International Edition, 2006. 45(23): p. 3878-3881.

87. Linser, R., et al., Proton-Detected Solid-State NMR Spectroscopy of Fibrillar and Membrane Proteins. Angewandte Chemie International Edition, 2011. 50(19): p. 4508-4512.

88. Paulson, E.K., et al., High-Sensitivity Observation of Dipolar Exchange and NOES between Exchangeable Protons in Proteins by 3D Solid-State NMR Spectroscopy. Journal of the American Chemical Society, 2003. 125(47): p. 14222-14223.

89. Retel, J.S., et al., Structure of outer membrane protein $G$ in lipid bilayers. Nature Communications, 2017. 8(1): p. 2073.

90. Sinnige, T., et al., Proton Clouds to Measure Long-Range Contacts between Nonexchangeable Side Chain Protons in Solid-State NMR. Journal of the American Chemical Society, 2014. 136(12): p. 4452-4455.

91. Andreas, L.B., et al., Structure and Mechanism of the Influenza A M218-60 Dimer of Dimers. Journal of the American Chemical Society, 2015. 137(47): p. 14877-14886.

92. Knight, M.J., et al., Structure and backbone dynamics of a microcrystalline metalloprotein by solid-state NMR. Proceedings of the National Academy of Sciences, 2012. 109(28): p. 11095-11100.

93. Knight, M.J., et al., Rapid Measurement of Pseudocontact Shifts in Metalloproteins by Proton-Detected Solid-State NMR Spectroscopy. Journal of the American Chemical Society, 2012. 134(36): p. 14730-14733.

94. Shi, L., et al., Conformation of a Seven-Helical Transmembrane Photosensor in the Lipid Environment. Angewandte Chemie International Edition, 2011. 50(6): p. 13021305.

95. Medeiros-Silva, J., et al., 1H-Detected Solid-State NMR Studies of Water-Inaccessible Proteins In Vitro and In Situ. Angewandte Chemie International Edition, 2016. 55(43): p. 13606-13610.

96. Smith, A.A., et al., Partially-deuterated samples of HET-s(218-289) fibrils: assignment and deuterium isotope effect. Journal of Biomolecular NMR, 2017. 67(2): p. 109-119.

97. Struppe, J., et al., Expanding the horizons for structural analysis of fully protonated protein assemblies by NMR spectroscopy at MAS frequencies above $100 \mathrm{kHz}$. Solid State Nuclear Magnetic Resonance, 2017. 87: p. 117-125.

98. Cala-De Paepe, D., et al., Is protein deuteration beneficial for proton detected solidstate NMR at and above $100 \mathrm{kHz}$ magic-angle spinning? Solid State Nuclear Magnetic Resonance, 2017.

99. Schubeis, T., et al., 1H NMR in solids evolves as a powerful new tool for membrane proteins. Journal of Magnetic Resonance, 2018(in press).

100. Asami, S., et al., Protein-RNA Interfaces Probed by 1H-Detected MAS Solid-State NMR Spectroscopy. Angewandte Chemie International Edition, 2013. 52(8): p. 23452349.

101. Andrew, E.R., A. Bradbury, and R.G. Eades, Nuclear Magnetic Resonance Spectra from a Crystal rotated at High Speed. Nature, 1958. 182: p. 1659.

102. Luca, S., et al., Secondary chemical shifts in immobilized peptides and proteins: $A$ qualitative basis for structure refinement under Magic Angle Spinning. Journal of Biomolecular NMR, 2001. 20(4): p. 325-331.

103. Bayro, M.J., et al., Dipolar truncation in magic-angle spinning NMR recoupling experiments. The Journal of Chemical Physics, 2009. 130(11): p. 114506.

104. Grommek, A., B.H. Meier, and M. Ernst, Distance information from proton-driven spin diffusion under MAS. Chemical Physics Letters, 2006. 427(4-6): p. 404-409. 
105. Hodgkinson, P. and L. Emsley, The accuracy of distance measurements in solid-state NMR. Journal of Magnetic Resonance, 1999. 139(1): p. 46-59.

106. Castellani, F., et al., Structure of a protein determined by solid-state magic-anglespinning NMR spectroscopy. Nature, 2002. 420: p. 98.

107. Loquet, A., et al., Supramolecular Interactions Probed by 13C-13C Solid-State NMR Spectroscopy. Journal of the American Chemical Society, 2010. 132(43): p. 1516415166.

108. Etzkorn, M., et al., Probing Molecular Interfaces Using 2D Magic-Angle-Spinning NMR on Protein Mixtures with Different Uniform Labeling. Journal of the American Chemical Society, 2004. 126(45): p. 14746-14751.

109. Debelouchina, G.T., et al., Intermolecular Alignment in $\beta(2)$-Microglobulin Amyloid Fibrils. Journal of the American Chemical Society, 2010. 132(48): p. 17077-17079.

110. Castellani, F., et al., Determination of Solid-State NMR Structures of Proteins by Means of Three-Dimensional 15N-13C-13C Dipolar Correlation Spectroscopy and Chemical Shift Analysis. Biochemistry, 2003. 42(39): p. 11476-11483.

111. Habenstein, B., et al., Structural characterization of supramolecular assemblies by $13 C$ spin dilution and 3D solid-state NMR. Journal of Biomolecular NMR, 2013. 55(1): p. $1-9$.

112. Loquet, A., et al., 13C spin dilution for simplified and complete solid-state NMR resonance assignment of insoluble biological assemblies. Journal of the American Chemical Society, 2011. 133(13): p. 4722-5.

113. Sen, A., et al., Mass analysis by scanning transmission electron microscopy and electron diffraction validate predictions of stacked beta-solenoid model of HET-s prion fibrils. Journal of Biological Chemistry, 2007. 282(8): p. 5545-50.

114. Goldsbury, C., et al., Amyloid structure and assembly: insights from scanning transmission electron microscopy. Journal of Structural Biology, 2011. 173(1): p. 113.

115. Linser, R., et al., Solid-State NMR Structure Determination from DiagonalCompensated, Sparsely Nonuniform-Sampled 4D Proton-Proton Restraints. Journal of the American Chemical Society, 2014. 136(31): p. 11002-11010.

116. Van Melckebeke, H., et al., Atomic-Resolution Three-Dimensional Structure of HETs(218-289) Amyloid Fibrils by Solid-State NMR Spectroscopy. Journal of the American Chemical Society, 2010. 132(39): p. 13765-13775.

117. Shen, Y., et al., TALOS+: a hybrid method for predicting protein backbone torsion angles from NMR chemical shifts. Journal of Biomolecular NMR, 2009. 44(4): p. 213-223.

118. Schutz, A.K., et al., Atomic-resolution three-dimensional structure of amyloid beta fibrils bearing the Osaka mutation. Angewandte Chemie International Edition, 2015. 54(1): p. 331-5.

119. Güntert, P., C. Mumenthaler, and K. Wüthrich, Torsion angle dynamics for NMR structure calculation with the new program Dyana. Journal of Molecular Biology, 1997. 273(1): p. 283-298.

120. Guerry, P. and T. Herrmann, Comprehensive Automation for NMR Structure Determination of Proteins, in Protein NMR Techniques, A. Shekhtman and D.S. Burz, Editors. 2012, Humana Press: Totowa, NJ. p. 429-451.

121. Bardiaux, B., T. Malliavin, and M. Nilges, ARIA for Solution and Solid-State NMR, in Protein NMR Techniques, A. Shekhtman and D.S. Burz, Editors. 2012, Humana Press: Totowa, NJ. p. 453-483.

122. Schwieters, C.D., et al., The Xplor-NIH NMR molecular structure determination package. Journal of Magnetic Resonance, 2003. 160(1): p. 65-73.

123. DiMaio, F., et al., Modeling Symmetric Macromolecular Structures in Rosetta3. PLoS One, 2011.6(6): p. e20450.

124. Fitzpatrick, A.W.P., et al., Atomic structure and hierarchical assembly of a cross- $\beta$ amyloid fibril. Proceedings of the National Academy of Sciences, 2013. 110(14): p. 5468-5473.

125. Nilges, M., A calculation strategy for the structure determination of symmetric demers by $1 H$ NMR. Proteins: Structure, Function, and Bioinformatics, 1993. 17(3): p. 297309. 
126. Lin, Y.-J., D.K. Kirchner, and P. Güntert, Influence of $1 H$ chemical shift assignments of the interface residues on structure determinations of homodimeric proteins. Journal of Magnetic Resonance, 2012. 222(Supplement C): p. 96-104.

127. He, L., et al., Structure determination of helical filaments by solid-state NMR spectroscopy. Proceedings of the National Academy of Sciences, 2016. 113(3): p. E272-E281.

128. Laskowski, R.A., et al., PROCHECK: a program to check the stereochemical quality of protein structures. Journal of Applied Crystallography, 1993(26): p. 283-291.

129. Davis, I.W., et al., MolProbity: all-atom contacts and structure validation for proteins and nucleic acids. Nucleic Acids Research, 2007.35(suppl_2): p. W375-W383.

130. Montelione, Gaetano T., et al., Recommendations of the ${ }_{W W P D B}$ NMR Validation Task Force. Structure, 2013. 21(9): p. 1563-1570.

131. van der Wel, P.C.A., Insights into protein misfolding and aggregation enabled by solid-state NMR spectroscopy. Solid State Nuclear Magnetic Resonance, 2017.

132. Kotler, S.A., et al., High-resolution NMR characterization of low abundance oligomers of amyloid- $\beta$ without purification. Scientific Reports, 2015. 5: p. 11811.

133. Wang, J., et al., Real-time monitoring of the aggregation of Alzheimer's amyloid- beta via $1 H$ magic angle spinning NMR spectroscopy. Chemical Communications, 2018. 54(16): p. 2000-2003.

134. Lee, M.-C., et al., Zinc ion rapidly induces toxic, off-pathway amyloid- $\beta$ oligomers distinct from amyloid- $\beta$ derived diffusible ligands in Alzheimer's disease. Scientific Reports, 2018. 8(1): p. 4772.

135. Hora, M., et al., MAK33 antibody light chain amyloid fibrils are similar to oligomeric precursors. PLoS One, 2017. 12(7): p. e0181799.

136. Bhowmik, D., et al., Cell-Membrane-Mimicking Lipid-Coated Nanoparticles Confer Raman Enhancement to Membrane Proteins and Reveal Membrane-Attached Amyloid- $\beta$ Conformation. ACS Nano, 2015. 9(9): p. 9070-9077.

137. Huang, D., et al., Antiparallel $\beta$-Sheet Structure within the $C$-Terminal Region of 42Residue Alzheimer's Amyloid- $\beta$ Peptides When They Form 150-kDa Oligomers. Journal of Molecular Biology, 2015. 427(13): p. 2319-2328.

138. Ahmed, M., et al., Structural conversion of neurotoxic amyloid- $\beta 1-42$ oligomers to fibrils. Nature Structural \& Molecular Biology, 2010. 17: p. 561.

139. Scheidt, H.A., et al., Solid-State NMR Spectroscopic Investigation of $A \beta$ Protofibrils: Implication of a $\beta$-Sheet Remodeling upon Maturation into Terminal Amyloid Fibrils. Angewandte Chemie International Edition, 2011. 50(12): p. 28372840.

140. Scheidt, H.A., I. Morgado, and D. Huster, Solid-state NMR Reveals a Close Structural Relationship between Amyloid- $\beta$ Protofibrils and Oligomers. Journal of Biological Chemistry, 2012. 287(27): p. 22822-22826.

141. Tay, W.M., et al., The Alzheimer's Amyloid- $\beta(1-42)$ Peptide Forms Off-Pathway Oligomers and Fibrils That Are Distinguished Structurally by Intermolecular Organization. Journal of Molecular Biology, 2013. 425(14): p. 2494-2508.

142. Lendel, C., et al., A Hexameric Peptide Barrel as Building Block of Amyloid- $\beta$ Protofibrils. Angewandte Chemie International Edition, 2014. 53(47): p. 1275612760.

143. Sarkar, B., et al., Significant Structural Differences between Transient Amyloid- $\beta$ Oligomers and Less-Toxic Fibrils in Regions Known To Harbor Familial Alzheimer's Mutations. Angewandte Chemie International Edition, 2014. 53(27): p. 6888-6892.

144. Parthasarathy, S., et al., Structural Insight into an Alzheimer's Brain-Derived Spherical Assembly of Amyloid $\beta$ by Solid-State NMR. Journal of the American Chemical Society, 2015. 137(20): p. 6480-6483.

145. Potapov, A., et al., Successive Stages of Amyloid- $\beta$ Self-Assembly Characterized by Solid-State Nuclear Magnetic Resonance with Dynamic Nuclear Polarization. Journal of the American Chemical Society, 2015. 137(25): p. 8294-8307.

146. Andreas, L.B., et al., Protein residue linking in a single spectrum for magic-angle spinning NMR assignment. Journal of Biomolecular NMR, 2015. 62(3): p. 253-61. 
147. Murray, D.T., et al., Structure of FUS Protein Fibrils and Its Relevance to SelfAssembly and Phase Separation of Low-Complexity Domains. Cell, 2017. 171(3): p. 615-627.e16.

148. Lee, M., et al., Zinc-binding structure of a catalytic amyloid from solid-state NMR. Proceedings of the National Academy of Sciences, 2017. 114(24): p. 6191-6196.

149. Nagy-Smith, K., et al., Molecular structure of monomorphic peptide fibrils within a kinetically trapped hydrogel network. Proceedings of the National Academy of Sciences, 2015. 112(32): p. 9816-21.

150. Schutz, A.K., et al., The amyloid-Congo red interface at atomic resolution. Angewandte Chemie International Edition, 2011. 50(26): p. 5956-60.

151. Nielsen, J.T., et al., Unique identification of supramolecular structures in amyloid fibrils by solid-state NMR spectroscopy. Angewandte Chemie International Edition, 2009. 48(12): p. 2118-21.

152. Iwata, K., et al., 3D structure of amyloid protofilaments of $\beta 2$-microglobulin fragment probed by solid-state NMR. Proceedings of the National Academy of Sciences, 2006. 103(48): p. 18119-18124.

153. Jaroniec, C.P., et al., High-resolution molecular structure of a peptide in an amyloid fibril determined by magic angle spinning NMR spectroscopy. Proceedings of the National Academy of Sciences, 2004. 101(3): p. 711-716. 


\section{Figures}

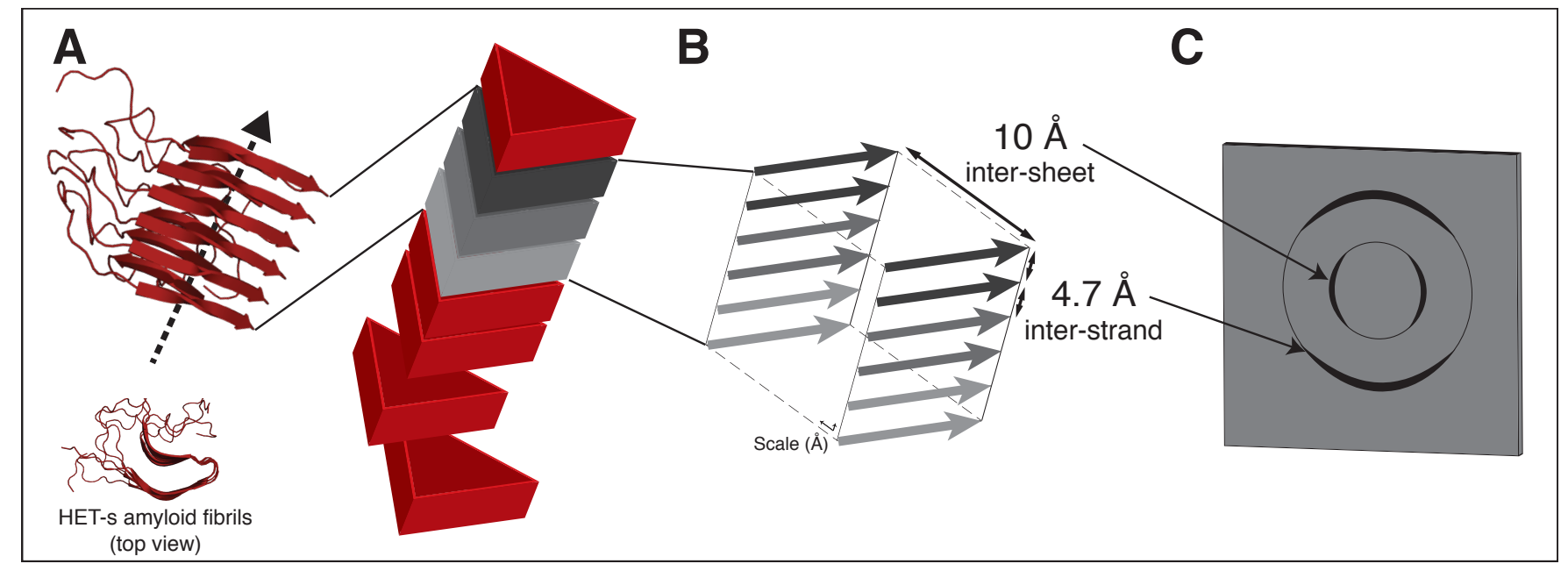

Fig.1: Structural features of amyloid fibrils.

A General morphology and monomer stacking of an amyloid fibril with HET-s fibrils [43] here used as an illustration with a singular two-layer $\beta$-solenoid amyloid fold; B representation of the so-called cross- $\beta$ quaternary structure in which $\beta$-sheets are stacked along the fibril axis with a $4.7 \AA$ spacing distance as interstrand interactions, and $10 \AA$ as inter-sheet contacts ; C schematic representation of a typical X-ray diffraction pattern, highly representative of the mentioned structural aspects associated with amyloid proteins. 


\begin{tabular}{|c|c|c|c|c|c|c|c|}
\hline$P D B$ & Protein & Organism & Length & Production & RMSD*1 & Authors*2 & Year $*^{2}$ \\
\hline $5 W 3 N$ & $\begin{array}{l}\text { RNA-binding } \\
\text { protein FUS }\end{array}$ & H. Sapiens & 241 & $\mathrm{R}$ & $0.99 \AA ̊ . \ldots$ & $\begin{array}{l}\text { Murray, D., } \\
\text { et. al. [147] }\end{array}$ & 2017 \\
\hline $5 U G K$ & $\begin{array}{l}\text { Catalytic zinc- } \\
\text { binding amyloid }\end{array}$ & Synthetic & 7 & $\mathrm{C}$ & $0.22 \AA / 0.31 \AA$ & $\begin{array}{l}\text { Lee, M., et } \\
\text { al. [148] }\end{array}$ & 2017 \\
\hline $5 K K 3$ & $A \beta-42$ & H. Sapiens & 42 & $\mathrm{R}$ & $0.67 \AA / 0.71 \AA$ & $\begin{array}{l}\text { Colvin, M. } \\
\text { T., et al. [46] }\end{array}$ & 2016 \\
\hline $2 N A O$ & $A \beta-42$ & H. Sapiens & 42 & $\mathrm{R}$ & $0.71 \AA / 0.89 \AA$ & $\begin{array}{l}\text { Walti, M. A., } \\
\text { et al. [45] }\end{array}$ & 2016 \\
\hline $2 N O A$ & a-synuclein & H. Sapiens & 140 & $\mathrm{R}$ & $\ldots / 1.5 \AA$ & $\begin{array}{c}\text { Tuttle, M.D., } \\
\text { et al. [44] }\end{array}$ & 2016 \\
\hline $2 N 1 E$ & MAX1 & Synthetic & 21 & $\mathrm{C}$ & $0.37 \AA / 2.08 \AA$ & $\begin{array}{l}\text { Nagy-Smith, } \\
\text { K., et al. } \\
\text { [149] }\end{array}$ & 2015 \\
\hline $2 M X U$ & $A \beta-42$ & H. Sapiens & 42 & C & $1.03 \AA / 1.08 \AA$ & $\begin{array}{c}\text { Xiao, Y., et } \\
\text { al. } \\
{[76]}\end{array}$ & 2015 \\
\hline $2 M P Z$ & $\begin{array}{l}\text { A } \beta-40 \text { mutant } \\
\text { D23N lowa }\end{array}$ & H. Sapiens & 26 & $\mathrm{C}$ & $2.26 \AA ̊ / 1.2 \AA$ & $\begin{array}{l}\text { Sgourakis, } \\
\text { N. G., et al. } \\
\text { [77] }\end{array}$ & 2015 \\
\hline $2 M V X$ & $\begin{array}{c}A \beta-40 \text { mutant } \\
\text { Osaka }\end{array}$ & H. Sapiens & 39 & $\mathrm{R}$ & $0.53 \AA / 0.8 \AA$ & $\begin{array}{l}\text { Schutz, A. } \\
\text { K., et al. } \\
\text { [118] }\end{array}$ & 2014 \\
\hline $2 M 4 J$ & $A \beta-40$ & H. Sapiens & 40 & $C, R$ & $1.19 \AA ̊ / 1.8 \AA$ & $\begin{array}{l}\text { Lu, J. X., et } \\
\text { al. [47] }\end{array}$ & 2013 \\
\hline $2 M 5 N$ & TTR(105-115) & H. Sapiens & 11 & $\mathrm{C}$ & $0.2 \AA / \ldots$ & $\begin{array}{l}\text { Fitzpatrick, } \\
\text { A. W. P., et } \\
\text { al. [124] }\end{array}$ & 2013 \\
\hline $2 L N Q$ & $\begin{array}{l}\text { A } \beta-40 \text { mutant } \\
\text { D23N }\end{array}$ & H. Sapiens & 40 & C & $0.81 \AA / 0.86 \AA$ & $\begin{array}{l}\text { Qiang. W., } \\
\text { et al. [78] }\end{array}$ & 2012 \\
\hline $2 L M N$ & $\begin{array}{c}A \beta-40 \\
\text { 2-f symmetry } \\
\text { positive stagger }\end{array}$ & H. Sapiens & 40 & $\mathrm{C}$ & $1.51 \AA ̊ / . .$. & $\begin{array}{c}\text { Tycko, R., et } \\
\text { al. [49] }\end{array}$ & 2011 \\
\hline $2 L M O$ & $\begin{array}{c}A \beta-40 \\
\text { 2-f symmetry } \\
\text { negative stagger }\end{array}$ & H. Sapiens & 40 & $\mathrm{C}$ & $1.36 \AA ̊ 丿 / . .$. & $\begin{array}{c}\text { Tycko, R., et } \\
\text { al. [49] }\end{array}$ & 2011 \\
\hline $2 L M P$ & $\begin{array}{c}A \beta-40 \\
\text { 3-f symmetry } \\
\text { positive stagger }\end{array}$ & H. Sapiens & 40 & $\mathrm{C}$ & $1.36 \AA 2 / 2.03 \AA$ & $\begin{array}{c}\text { Tycko, R., et } \\
\text { al. [49] }\end{array}$ & 2011 \\
\hline $2 L M Q$ & $\begin{array}{c}A \beta-40 \\
\text { 3-f symmetry } \\
\text { negative stagger }\end{array}$ & H. Sapiens & 40 & C & $1.55 \AA / 2.03 \AA$ & $\begin{array}{c}\text { Tycko, R., et } \\
\text { al. [49] }\end{array}$ & 2011 \\
\hline $2 L B U$ & $\begin{array}{l}\text { HET-s amyloid } \\
\text { with Congo red }\end{array}$ & P. anserina & 79 & $\mathrm{R}$ & $0.27 \AA / 0.55 \AA$ & $\begin{array}{c}\text { Schutz, A. } \\
\text { K., et al. } \\
\text { [150] }\end{array}$ & 2011 \\
\hline $2 K J 3$ & HET-s(218-289) & P. anserina & 79 & $\mathrm{R}$ & $0.68 \AA / 0.64 \AA$ & $\begin{array}{c}\text { Van } \\
\text { Melckebeke, } \\
\text { H., et al. } \\
\text { [116] }\end{array}$ & 2009 \\
\hline $2 K I B$ & hIAPP(23-29) & Synthetic & 7 & $\mathrm{C}$ & $0.52 \AA / 0.52 \AA$ & $\begin{array}{l}\text { Nielsen, J. } \\
\text { T., et al. } \\
\text { Isen [151] }\end{array}$ & 2009 \\
\hline 2RNM & HET-s(218-289) & P. anserina & 79 & $\mathrm{R}$ & $0.72 \AA / 0.63 \AA$ & $\begin{array}{c}\text { Wasmer, C., } \\
\text { et al. [43] }\end{array}$ & 2008 \\
\hline $2 E 8 D$ & $\begin{array}{c}\beta-2- \\
\text { microglobulin }\end{array}$ & H. Sapiens & 22 & $C, R$ & $1.14 \AA / 1.43 \AA$ & $\begin{array}{c}\text { Fujiwara, T. } \\
\text { [152] }\end{array}$ & 2007 \\
\hline $2 N N T$ & $\begin{array}{l}\text { Transcription } \\
\text { elongation } \\
\text { regulator } 1 \\
\text { (Human CA150) }\end{array}$ & H. Sapiens & 40 & $\mathrm{C}$ & $0.27 \AA / 1.23 \AA$ & $\begin{array}{l}\text { Ferguson, } \\
\text { N., et al. } \\
\text { [79] }\end{array}$ & 2006 \\
\hline $1 R V S$ & TTR(105-115) & R. novegicus & 11 & $\mathrm{C}$ & $\ldots / 0.69 \AA$ & $\begin{array}{c}\text { Jaroniec, C. } \\
\text { P., et al. } \\
\text { [153] }\end{array}$ & 2004 \\
\hline
\end{tabular}


Table 1: List of all 23 entries in the PDB corresponding to amyloid proteins analysed using SSNMR.

${ }^{* 1}$ Two RMSD values are displayed depending on the source: $p d b /$ publication. "..." is displayed whenever associated values could not be found.

$*^{2}$ Both indicated year and authors are related to the PDB deposition (could differ from associated paper publication). 


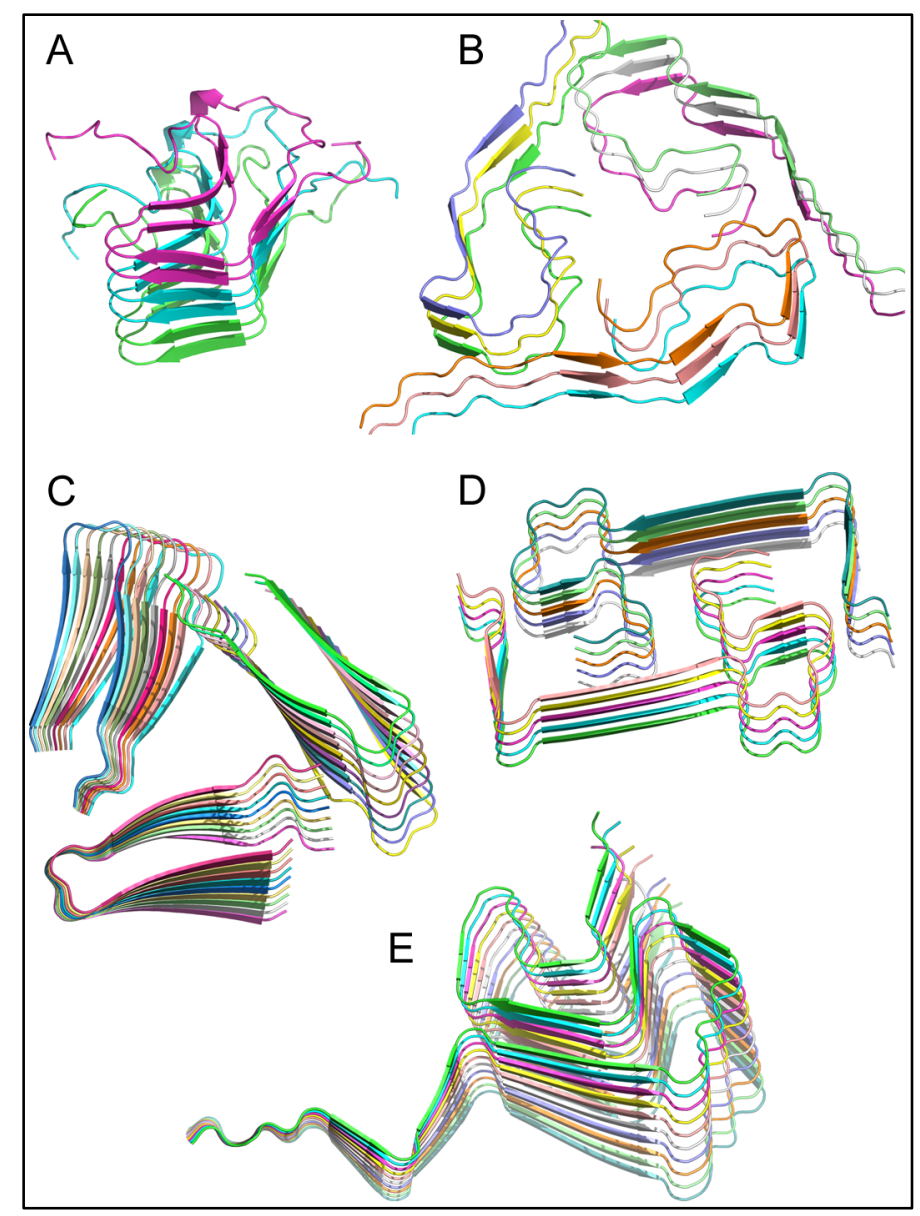

Fig.2: Selection of amyloid fibrils atomic structures determined by solid-state NMR.

A HET-s(218-289) prion fibrils, automated calculation with CYANA (PDB 2KJ3) [116]; B A $\beta_{1-40}$ fibrils in Alzheimer's disease brain tissue, manual calculation with XPLOR-NIH (PDB 2M4J) [47]; C A $\beta_{1-40}$ D23N "Iowa" mutant fibrils, manual calculation with Rosetta (PDB 2MPZ) [77]; D A $\beta_{1-40}$ E22 $\Delta$ "Osaka" mutant fibrils, automated calculation with CYANA (PDB 2MVX) [118]; E Human $\alpha$-synuclein fibrils, manual calculation with XPLOR-NIH (PDB 2N0A) [44]. Figure was generated with the PyMOL Molecular Graphics System (Schrödinger, LLC). 


\begin{tabular}{|c|c|c|c|c|c|c|c|}
\hline$P D B$ & Protein & Prod. & $\begin{array}{l}\text { Extrac./ } \\
\text { Purif.*² }\end{array}$ & Assembly ${ }^{* 3}$ & Labelling & Pub. ${ }^{4}$ & Year \\
\hline $5 W 3 N$ & $\begin{array}{l}\text { RNA-binding } \\
\text { protein FUS }\end{array}$ & R & To be published & To be published & To be published & $\begin{array}{l}\text { Murray, D., } \\
\text { T., et. al. } \\
\text { [147] }\end{array}$ & 2017 \\
\hline $5 U G K$ & $\begin{array}{l}\text { Catalytic zinc- } \\
\text { binding } \\
\text { amyloid }\end{array}$ & C & $\begin{array}{l}\text {-Designed } \\
\text { sequence } \\
\text {-Fmoc-protection } \\
\text {-Solid-phase } \\
\text { synthesis } \\
\text {-HPLC purification }\end{array}$ & $\begin{array}{l}\text {-Excess of zinc ( 1.5- } \\
\text { fold) } \\
-\mathrm{pH} 8 \text { Tris buffer with } \\
\text { or without } \mathrm{ZnCl} 2, \text { with } \\
\text { or without urea } \\
\text {-RT }\end{array}$ & $\begin{array}{l}-10 \text { derivatives } \\
\text { of ILV labelling } \\
\text {-Scattered } \\
\text { labelling }\end{array}$ & $\begin{array}{l}\text { Lee, M., et } \\
\text { al. [148] }\end{array}$ & 2017 \\
\hline $5 K K 3$ & $A \beta-42$ & $\mathrm{R}$ & $\begin{array}{l}\text {-Inclusion-body } \\
\text { extraction in } 8 \mathrm{M} \\
\text { urea } \\
\text {-lon-exchange } \\
\text { chromatography in } \\
\text { batch-mode } \\
\text {-Two size exclusion } \\
\text { chromatography } \\
\text { steps }\end{array}$ & $\begin{array}{l}\text {-pH 8, } 20 \mathrm{mM} \text { sodium } \\
\text { phosphate, } 0.2 \mathrm{mM} \\
\text { EDTA, } 0.02 \% \mathrm{NaN} 3 \\
-10-50 \mu \mathrm{M} \\
(0.05-0.25 \mathrm{mg} / \mathrm{mL}) \\
-\mathrm{RT} \text {, overnight }\end{array}$ & $\begin{array}{l}-U-{ }^{13} \mathrm{C}^{-15} \mathrm{~N} \\
-1,6-{ }^{13} \mathrm{C}_{2^{-}} \\
\text {glucosse } \\
-\mathrm{U}^{13} \mathrm{C}-{ }^{15} \mathrm{~N} / \\
\mathrm{N} \cdot \mathrm{A}^{* 5}(3: 7) \\
\left.-3-{ }^{13} \mathrm{C}-\text { glycerol }\right) \\
/ \mathrm{U}-{ }^{15} \mathrm{~N}(1: 1) \\
-2-{ }^{-13} \mathrm{C}-\text { glycerol / } \\
1,3-{ }^{13} \mathrm{C}_{2}- \\
\text { glycerol }(1: 1)\end{array}$ & $\begin{array}{l}\text { Colvin, M. } \\
\text { T., et al. [46] }\end{array}$ & 2016 \\
\hline $2 N A O$ & $A \beta-42$ & $\mathrm{R}$ & $\begin{array}{l}\text {-(NANP) }{ }_{19} \text {-tagged } \\
\text { (fusion protein) } \\
\text {-Inclusion bodies } \\
\text { extraction with 6M } \\
\text { guanidinium } \\
\text { chloride }(\mathrm{GdmCl}) \\
\text {-Affinity } \\
\text { chromatography } \\
\text {-RP-HPLC } \\
\text {-TEV protease } \\
\text { cleavage } \\
\text {-Lyophilisation }\end{array}$ & $\begin{array}{l}\text {-Dissolved in } 10 \mathrm{mM} \\
\mathrm{NaOH} \\
\text {-Sonication } \\
\text {-Ultra-centrifuged at } \\
126000 \mathrm{~g} \\
\text {-Phosphate buffer } \\
\text { added, up to } 100 \mathrm{mM} \text {, } \\
\mathrm{pH} 7.4 \\
-30 / 150 \mu \mathrm{M} \\
-37^{\circ} \mathrm{C}, \text { with shaking } \\
- \text { Seeding performed } \\
\text { for three generations, } \\
\text { with } 10 \% \text { of seeds } \\
\text { each time }\end{array}$ & $\begin{array}{l}-U-{ }^{13} C-{ }^{15} \mathrm{~N} \\
-U-{ }^{15} \mathrm{~N} / \mathrm{U}-{ }^{13} \mathrm{C} \\
(1: 1) \\
-U-{ }^{13} \mathrm{C}-{ }^{15} \mathrm{~N} / \mathrm{NA} \\
(1: 3)\end{array}$ & $\begin{array}{l}\text { Walti, M. } \\
\text { A., et al. } \\
\text { [45] }\end{array}$ & 2016 \\
\hline $2 N O A$ & a-synuclein & R & $\begin{array}{l}\text {-Hydrophobic } \\
\text { interaction } \\
\text { chromatography } \\
\text {-Size exclusion } \\
\text { chromatography }\end{array}$ & $\begin{array}{l}\text { - Sodium phosphate } \\
\text { buffer }(50 \mathrm{mM}, \mathrm{pH} \\
7.4) \text { with } 0.1 \mathrm{mM} \\
\text { EDTA, and } 0.02 \% \\
\text { azide }(\mathrm{W} / \mathrm{V}) \\
-15 \mathrm{mg} / \mathrm{mL} \\
-37^{\circ} \mathrm{C} \text { with shaking at } \\
200 \mathrm{rpm} \text { for } 3 \text { weeks }\end{array}$ & $\begin{array}{l}-U-{ }^{13} \mathrm{C}_{-15}^{15} \mathrm{~N} \\
-1,3-{ }^{13} \mathrm{C}_{2}- \\
\text { glycerol- }{ }^{-15} \mathrm{~N} \\
-2-^{13} \mathrm{C} \text {-glycerol- } \\
{ }^{15} \mathrm{~N} \\
-\mathrm{U}^{13}{ }^{13} \mathrm{C}-{ }^{15} \mathrm{~N} / \mathrm{N} . \mathrm{A} \\
(1: 3) \\
-1,3-{ }^{13} \mathrm{C}_{2}- \\
\text { glycerol / U- }{ }^{15} \mathrm{~N} \\
(1: 1) \\
-2--^{13} \mathrm{C}-\text { glycerol / } \\
\mathrm{U}-{ }^{15} \mathrm{~N}(1: 1)\end{array}$ & $\begin{array}{l}\text { Tuttle, M.D., } \\
\text { et al. [44] }\end{array}$ & 2016 \\
\hline $2 N 1 E$ & MAX1 & C & $\begin{array}{l}\text {-Solid-phase } \\
\text { synthesis } \\
\text {-Fmoc protection / } \\
\text { HCTU activation } \\
\text {-RP-HPLC } \\
\text { purification } \\
\text {-Lyophilisation }\end{array}$ & $\begin{array}{l}\text {-pH 9, } 250 \mathrm{mM} \text { bis- } \\
\text { Tris propane buffer, } \\
20 \mathrm{mM} \mathrm{NaCl} \\
\text {-RT for } 2 \mathrm{~h}\end{array}$ & $\begin{array}{l}\text {-Scattered } \\
\text { labelling } \\
\text {-Either }{ }^{13} \mathrm{C} \text { - } \\
\text { single-site, on } 1 \\
\text { or } 2 \text { residues } \\
- \text { Or } U-{ }^{13} \mathrm{C}^{-15} \mathrm{~N} \\
\text { on } 3 \text { to } 5 \\
\text { residues at the } \\
\text { same time } \\
-11 \text { samples in } \\
\text { total }\end{array}$ & $\begin{array}{l}\text { Nagy-Smith, } \\
\text { K., et al. } \\
\text { [149] }\end{array}$ & 2015 \\
\hline $2 M X U$ & $\mathrm{~A} \beta-42$ & C & $\begin{array}{l}\text {-Solid-phase } \\
\text { synthesis } \\
\text {-Fmoc protection / } \\
\text { HCTU activation } \\
\text {-RP-HPLC } \\
\text { purification }\end{array}$ & $\begin{array}{l}-\mathrm{pH} 7.4,10 \mathrm{mM} \\
\text { phosphate buffer } \\
-60 \mu \mathrm{M} \\
- \text { Sonication cycles } \\
\text { (with } 10 \% \text { w/w seeds } \\
\text { each time) until } 4^{\text {th }} \\
\text { generation } \\
-\mathrm{RT} \text {, one-week } \\
\text { incubation }\end{array}$ & $\begin{array}{l}\text { - Scattered } \\
\text { labelling } \\
-U-{ }^{13} \mathrm{C}-{ }^{15} \mathrm{~N} \\
\text { residue-specific } \\
\text { labelling } \\
-17 \text { samples in } \\
\text { total } \\
- \text { Including U- } \\
{ }^{13} \mathrm{C}-{ }^{-15} \mathrm{~N} / \mathrm{N} . \mathrm{A} . \\
(1: 1)\end{array}$ & $\begin{array}{l}\text { Xiao, Y., et } \\
\text { al. [76] }\end{array}$ & 2015 \\
\hline $2 M P Z$ & $\begin{array}{l}\text { A } \beta \text { D23N } \\
\text { lowa mutation }\end{array}$ & C & $\begin{array}{l}\text {-Solid-phase } \\
\text { synthesis }\end{array}$ & $\begin{array}{l}-\mathrm{pH} 7.4,10 \mathrm{mM} \\
\text { phosphate buffer, }\end{array}$ & $\begin{array}{l}-8 \text { samples in } \\
\text { total }\end{array}$ & $\begin{array}{l}\text { Sgourakis, } \\
\text { N. G., et al. }\end{array}$ & 2015 \\
\hline
\end{tabular}




\begin{tabular}{|c|c|c|c|c|c|c|c|}
\hline & & & $\begin{array}{l}\text {-Fmoc protection } \\
\text {-HPLC purification } \\
\text {-Lyophilisation }\end{array}$ & $\begin{array}{l}0.01 \% \text { NaN3 } \\
-100 \mu \mathrm{M} \\
-4^{\circ} \mathrm{C} \text {, one-week } \\
\text { incubation } \\
\text {-Seeds prepared with } \\
10 \% \text { sonicated }\left(1^{\text {st }}\right. \\
\text { generation) } \\
- \text { - Incubation for } 4 \mathrm{~h} \text { at } \\
4^{\circ} \mathrm{C} \text {, cycles until } 8^{\text {th }} \\
\text { generation }\end{array}$ & $\begin{array}{l}-\mathrm{U}-{ }^{13} \mathrm{C}-{ }^{15} \mathrm{~N} \\
\text { scattered } \\
\text { labelling } \\
\text { (residue- } \\
\text { specific) }\end{array}$ & [77] & \\
\hline $2 M V X$ & $\begin{array}{l}\text { A } \beta \text { Osaka } \\
\text { mutation }\end{array}$ & $\mathrm{R}$ & $\begin{array}{l}\text {-Inclusion bodies } \\
\text { extraction with } 6 \mathrm{M} \\
\text { guanidinium } \\
\text { chloride (GdmCl) } \\
\text {-Affinity } \\
\text { chromatography } \\
\text { (RP-HPLC) } \\
\text {-TEV protease } \\
\text { cleavage }\end{array}$ & $\begin{array}{l}-\mathrm{pH} 7.4,10 \mathrm{mM} \\
\mathrm{NaH} 2 \mathrm{PO} 4-\mathrm{NaOH}, \\
100 \mathrm{mM} \mathrm{NaCl} \\
-60 \mu \mathrm{M} \\
-37^{\circ} \mathrm{C} \text {, magnetic } \\
\text { stirring at } 700 \mathrm{rpm}, 80 \\
\text { min }\end{array}$ & $\begin{array}{l}-U-{ }^{15} \mathrm{~N} / \mathrm{U}-{ }^{13} \mathrm{C} \\
(1: 1) \\
-U-{ }^{-13} \mathrm{C}-{ }^{15} \mathrm{~N} / \\
\text { N.A. }(1: 4) \\
-U-{ }^{-13} \mathrm{C}-{ }^{15} \mathrm{~N} \\
-U-{ }^{-13} \mathrm{C} \\
-{ }^{15} \mathrm{~N}-2-{ }^{13} \mathrm{C}- \\
\text { glucose }\end{array}$ & $\begin{array}{l}\text { Schutz, A. } \\
\text { K., et al. } \\
\text { [118] }\end{array}$ & 2014 \\
\hline $2 M 4 J$ & $A \beta-40$ & $\mathrm{C} / \mathrm{R}$ & $\begin{array}{l}\text { Both chemical or } \\
\text { recombinant } \\
\text { production for } A \beta \\
\text { peptides }\end{array}$ & $\begin{array}{l}\text {-pH } 7.4,10 \mathrm{mM} \\
\text { phosphate buffer } \\
\text {-Grown at } 24^{\circ} \mathrm{C} \text { with } \\
5 \mathrm{mg} / \mathrm{mL} \text { brain } \\
\text { extract, and } 100 \mu \mathrm{M} \\
\text { peptide }\end{array}$ & $\begin{array}{l}-U-{ }^{13} \mathrm{C}-{ }^{15} \mathrm{~N} \\
-\mathrm{U}-{ }^{13} \mathrm{C}-{ }^{15} \mathrm{~N} \\
\text { scattering } \\
\text {-Selectively }{ }^{13} \mathrm{C} \text { - } \\
\text { labeled sites }\end{array}$ & $\begin{array}{l}\text { Lu, J. X., et } \\
\text { al. [47] }\end{array}$ & 2013 \\
\hline $2 M 5 N$ & TTR(105-115) & C & $\begin{array}{l}\text {-Solid-phase } \\
\text { chemical methods } \\
\text {-HPLC purification }\end{array}$ & $\begin{array}{l}-\mathrm{pH} 2,10 \% \mathrm{v} / \mathrm{v} \\
\text { acetonitrile } / \mathrm{H} 2 \mathrm{O} \\
-15 \mathrm{mg} / \mathrm{mL} \\
-37^{\circ} \mathrm{C} \text {, two days, then } \\
\text { RT, } 14 \text { days }\end{array}$ & $\begin{array}{l}-2 \text { scattered U- } \\
{ }^{13} \mathrm{C}-{ }^{-15} \mathrm{~N} \\
\text { samples } \\
-1 \text { sample with } \\
{ }^{13} \mathrm{C} \text {-labeling at } \\
\text { one site and } \\
{ }^{15} \mathrm{~N} \text {-labelling at } \\
\text { another }\end{array}$ & $\begin{array}{l}\text { Fitzpatrick, } \\
\text { A. W. P., et } \\
\text { al. [124] }\end{array}$ & 2013 \\
\hline $2 L N Q$ & $\begin{array}{l}\mathrm{A} \beta-40 \mathrm{D} 23 \mathrm{~N} \\
\text { mutation }\end{array}$ & C & $\begin{array}{l}\text {-Solid-phase } \\
\text { methods } \\
\text {-Fmoc chemistry } \\
\text {-RP-HPLC } \\
\text { purification }\end{array}$ & $\begin{array}{l}-\mathrm{pH} 7.4,10 \mathrm{mM} \\
\text { sodium phosphate, } \\
0.01 \% \mathrm{NaN3} \\
-100 \mu \mathrm{M} \\
-1 \mathrm{st} \text { generation seeds } \\
\text { after } 7 \text { days at } 6^{\circ} \mathrm{C}, \\
\text { then sonication } \\
\text { cycles of } 3 \mathrm{~h} \\
\text { incubation periods at } \\
6^{\circ} \mathrm{C} \text { until } 8^{\text {th }} \\
\text { generation }\end{array}$ & $\begin{array}{l}-U-{ }^{13} \mathrm{C}-{ }^{15} \mathrm{~N} \\
\text { labelling for } \\
\text { certain residues } \\
\text { (residue- } \\
\text { specific } \\
\text { scattering) } \\
-5 \text { samples in } \\
\text { total }\end{array}$ & $\begin{array}{l}\text { Qiang. W., et } \\
\text { al. [78] }\end{array}$ & 2012 \\
\hline $2 L M N$ & $\begin{array}{l}2 \text { fold } \\
\text { symmetry } A \beta- \\
40 \text { positive } \\
\text { stagger }\end{array}$ & C & $\begin{array}{l}\text {-Solid-phase } \\
\text { methods } \\
\text {-FMOC-chemistry / } \\
\text { HBTU activation } \\
\text {-HPLC purification } \\
\text {-Lyophilisation }\end{array}$ & $\begin{array}{l}-\mathrm{pH} 7.4,10 \mathrm{mM} \\
\text { sodium phosphate, } \\
0.01 \% \text { azide } \\
-210 \mu \mathrm{M} \\
- \text { Sonication/filtration } \\
\text { cycles (with } 10 \% \\
\text { seeds each time) until } \\
12^{\text {th }} \text { generation }\end{array}$ & $\begin{array}{l}-\mathrm{U}-{ }^{13} \mathrm{C}-{ }^{15} \mathrm{~N} \\
\text { (residue- } \\
\text { specific } \\
\text { scattering) } \\
-{ }^{13} \mathrm{C} \text {-labeled } \\
\mathrm{Sites} \\
-{ }^{15} \mathrm{~N} \text {-labeled } \\
\text { residues } \\
-15 \text { samples in } \\
\text { total }\end{array}$ & $\begin{array}{l}\text { Tycko, R., et } \\
\text { al. [49] }\end{array}$ & 2011 \\
\hline $2 L M O$ & $\begin{array}{l}2 \text { fold } \\
\text { symmetry } A \beta- \\
40 \text { negative } \\
\text { stagger }\end{array}$ & & * & * & * & $\begin{array}{l}\text { Tycko, R., et } \\
\text { al. [49] }\end{array}$ & 2011 \\
\hline $2 L M P$ & $\begin{array}{l}3 \text { fold } \\
\text { symmetry A }- \\
40 \text { positive } \\
\text { stagger }\end{array}$ & & * & * & * & $\begin{array}{l}\text { Tycko, R., et } \\
\text { al. [49] }\end{array}$ & 2011 \\
\hline $2 L M Q$ & $\begin{array}{l}3 \text { fold } \\
\text { symmetry } A \beta- \\
40 \text { negative } \\
\text { stagger }\end{array}$ & C & * & * & * & $\begin{array}{l}\text { Tycko, R., et } \\
\text { al. [49] }\end{array}$ & 2011 \\
\hline $2 L B U$ & $\begin{array}{l}\text { HET-s } \\
\text { amyloid } \\
\text { bound to } \\
\text { Congo red }\end{array}$ & $\mathrm{R}$ & $\begin{array}{l}\text { (Same as Wasmer } \\
\text { et. al. 2008) } \\
\text {-Inclusion body } \\
\text { extraction in } 6 \mathrm{M} \\
\mathrm{Gu}-\mathrm{HCl} \\
\text { - His-affinity } \\
\text { chromatography }\end{array}$ & $\begin{array}{l}\text {-Increase } \mathrm{pH} \text { to } 7.5 \\
\text { by adding Tris } \mathrm{pH} 8 \\
-25^{\circ} \mathrm{C} \text { incubation }\end{array}$ & $\begin{array}{l}-\mathrm{U}-{ }^{13} \mathrm{C}-{ }^{15} \mathrm{~N} \\
\text {-Natural } \\
\text { abundance } \\
-\mathrm{U}-{ }^{2} \mathrm{H}-{ }^{13} \mathrm{C}-{ }^{15} \mathrm{~N}\end{array}$ & $\begin{array}{l}\text { Schutz, A. } \\
\text { K., et al. } \\
\text { [150] }\end{array}$ & 2011 \\
\hline
\end{tabular}




\begin{tabular}{|c|c|c|c|c|c|c|c|}
\hline & & & $\begin{array}{l}\text {-Desalting in acetic } \\
\text { acid }\end{array}$ & & & & \\
\hline $2 K J 3$ & $\begin{array}{l}\text { HET-s(218- } \\
289)\end{array}$ & $\mathrm{R}$ & $\begin{array}{l}\text {-Inclusion body } \\
\text { extraction in } 7.5 \mathrm{M} \\
\mathrm{Gu}-\mathrm{HCl} \\
\text {-Ni-affinity column } \\
\text {-Buffer exchange to } \\
\text { acetic acid }\end{array}$ & $\begin{array}{l}\text {-Addition of Tris } \mathrm{pH} 8 \\
\text { to } \mathrm{pH} 7.5 \\
-25^{\circ} \mathrm{C} \text { incubation }\end{array}$ & $\begin{array}{l}-2-{ }^{13} \mathrm{C} \text {-glycerol / } \\
\text { N.A. }(1: 2.5) \\
-1,3-{ }^{13} \mathrm{C}_{2-} \\
\text { glycerol / N.A. } \\
(1: 2.5) \\
-U-{ }^{13} \mathrm{C}-{ }^{15} \mathrm{~N} / \mathrm{NA} \\
(1: 2.5) \\
-U-{ }^{13} \mathrm{C} / \mathrm{U}-{ }^{15} \mathrm{~N} \\
(1: 1) \\
-2-{ }^{13} \mathrm{C}-\mathrm{glycerol} \\
-U-{ }^{13} \mathrm{C}-{ }^{15} \mathrm{~N}\end{array}$ & $\begin{array}{l}\text { Van } \\
\text { Melckebeke, } \\
\text { H., et al. } \\
{[116]}\end{array}$ & 2009 \\
\hline $2 K I B$ & hIAPP (23-29) & C & $\begin{array}{l}\text {-Solid-phase } \\
\text { synthesis } \\
\text {-Fmoc-protection } \\
\text {-HPLC purification }\end{array}$ & 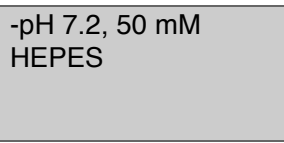 & $\begin{array}{l}-U-{ }^{13} \mathrm{C}-{ }^{15} \mathrm{~N} \\
- \text { Single sample }\end{array}$ & $\begin{array}{l}\text { Nielsen, J. } \\
\mathrm{T} ., \text { et al. } \\
\text { [151] }\end{array}$ & 2009 \\
\hline 2RNM & $\begin{array}{l}\text { HET-s(218- } \\
289)\end{array}$ & $\mathrm{R}$ & $\begin{array}{l}\text { (Same as Wasmer } \\
\text { et. al. 2008) } \\
\text {-Inclusion body } \\
\text { extraction in } 6 \mathrm{M} \\
\text { Gu-HCl } \\
\text {-His-affinity } \\
\text { chromatography } \\
\text {-Desalting in acetic } \\
\text { acid }\end{array}$ & $\begin{array}{l}-\mathrm{pH} \text { increased to } 7.5 \\
\text { by adding Tris } \mathrm{pH} 8 \\
-25^{\circ} \mathrm{C} \text { incubation }\end{array}$ & 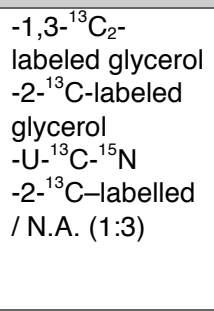 & $\begin{array}{l}\text { Wasmer, C., } \\
\text { et al. [43] }\end{array}$ & 2008 \\
\hline $2 E 8 D$ & $\begin{array}{l}\beta-2- \\
\text { microglobulin }\end{array}$ & $\mathrm{R} / \mathrm{C}$ & $\begin{array}{l}\text { Full-Length: } \\
\text {-Inclusion body } \\
\text { extraction with } 8 \mathrm{M} \\
\text { urea in Tris-HCl pH } \\
8 \\
\text {-RP-HPLC } \\
\text {-Dialysis/Size- } \\
\text { exclusion with } \mathrm{NaCl} \\
\text { gradient } \\
\text { K3 peptide: } \\
\text {-Digestion of } \beta-2-\mathrm{m} \\
\text { with lysyl- } \\
\text { endopeptidase / } \\
\text { Fmoc-solid-phase } \\
\text { methods }\end{array}$ & $\begin{array}{l}-20 \%(\mathrm{v} / \mathrm{v}) \mathrm{TFE}, 10 \\
\mathrm{mM} \mathrm{HCl}, 1 \mathrm{mM} \mathrm{NaCl} \\
-100 \mu \mathrm{M} \\
-25^{\circ} \mathrm{C} \text {, one day }\end{array}$ & $\begin{array}{l}-U-{ }^{13} \mathrm{C}-{ }^{15} \mathrm{~N} \\
-\mathrm{U}^{13} \mathrm{C}-{ }^{15} \mathrm{~N} / \\
\text { N.A. }(1: 2)\end{array}$ & $\begin{array}{l}\text { Fujiwara, } T . \\
\text { [152] }\end{array}$ & 2007 \\
\hline $2 N N T$ & $\begin{array}{l}\text { Transcription } \\
\text { elongation } \\
\text { regulator } 1 \\
\text { (Human } \\
\text { CA150) }\end{array}$ & C & $\begin{array}{l}\text {-Solid-phase } \\
\text { methods } \\
\text {-Fmoc-protection } \\
\text {-Gel filtration } \\
\text {-Reversed-phase } \\
\text { chromatography } \\
\text {-Lyophilisation }\end{array}$ & $\begin{array}{l}-\mathrm{pH} 7,10 \mathrm{mM} \text { sodium } \\
\text { phosphate, } 0.02 \% \\
\text { azide } \\
\text {-Sonication/filtration } \\
\text { in water bath } \\
-100 \mu \mathrm{M}\end{array}$ & $\begin{array}{l}-U-{ }^{13} \mathrm{C}-{ }^{15} \mathrm{~N} \\
-2-{ }^{-13} \mathrm{C}-\text { glycerol- } \\
{ }^{15} \mathrm{~N} \\
-1,3-{ }^{13} \mathrm{C}_{2^{-}} \\
\text {glycerol- }{ }^{-15} \mathrm{~N} \\
-\mathrm{U}^{2}{ }^{-} \mathrm{H}^{13}{ }^{3} \mathrm{C}-{ }^{15} \mathrm{~N} \\
\text { (water- } \\
\text { exchanged) }\end{array}$ & $\begin{array}{l}\text { Ferguson, } \\
\text { N., et al. [79] }\end{array}$ & 2006 \\
\hline $1 R V S$ & TTR(105-115) & C & $\begin{array}{l}\text {-Solid-phase } \\
\text { methods } \\
\text {-HPLC purification }\end{array}$ & $\begin{array}{l}-\mathrm{pH} 2,10 \% \\
\text { acetonitrile / water } \\
\text { solution } \\
-15 \mathrm{mg} / \mathrm{mL} \\
-37^{\circ} \mathrm{C} \text {, two days, then } \\
\mathrm{RT}, 14 \text { days }\end{array}$ & $\begin{array}{l}- \text { Scattering U- } \\
{ }^{13} \mathrm{C}-{ }^{-15} \mathrm{~N} \\
\text { labelling, with } 3 \\
\text { consecutive } \\
\text { stretches of } \\
\text { four residues } \\
\text { from position } \\
105 \text { to } 115 \\
-3 \text { samples in } \\
\text { total }\end{array}$ & $\begin{array}{l}\text { Jaroniec, C. } \\
\text { P., et al. } \\
\text { [153] }\end{array}$ & 2004 \\
\hline
\end{tabular}

Table 2: Overview of all production/assembly/labelling strategies for all 23 amyloid proteins analysed using SSNMR found on the PDB (listed in Table 1)

\section{${ }^{* 1}$ Production}

$*^{2}$ Extraction / Purification

$*^{3}$ Following assembly the sample is each time pelleted, washed several times and packed into a SSNMR rotor.

${ }^{*}$ Related publication

$*^{5}$ N.A. $=$ proteins at natural abundance 


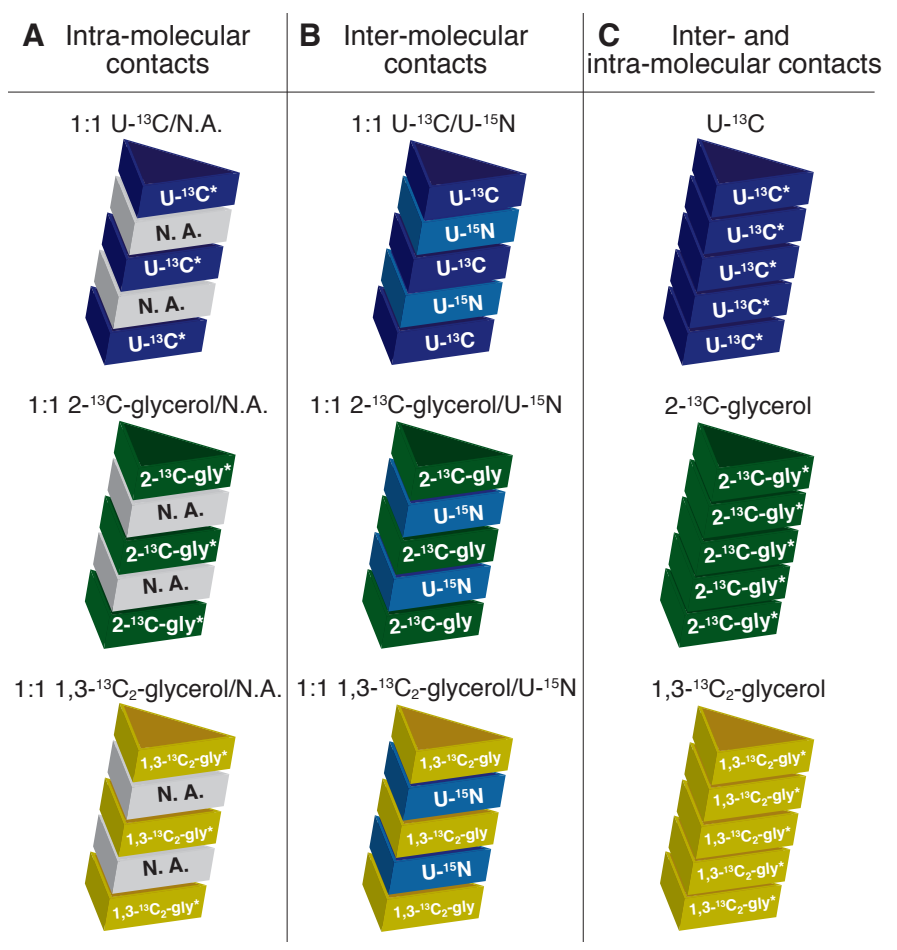

Fig.3: Labelling schemes utilized for amyloid structure determination using SSNMR.

(NB: * is added when ${ }^{15} \mathrm{~N}$-labelling can be added if ${ }^{15} \mathrm{~N}$-detected SSNMR experiments are required)

$\mathrm{A}$ any mix between ${ }^{13} \mathrm{C}$-labelled and unlabelled (natural abundance, N.A.) proteins will distinctly prevent intermonomer ${ }^{13} \mathrm{C}-{ }^{13} \mathrm{C}$ correlations, thus allowing the unambiguous discrimination between inter- and intra-molecular interactions; B any mix between ${ }^{13} \mathrm{C}$-labelled and ${ }^{15} \mathrm{~N}$-labelled proteins is extremely helpful in determining the fibril stacking registry (i.e. in or out); $\mathrm{C}$ both inter- and intra-monomer interactions can be detected, while specific ${ }^{13} \mathrm{C}$-glycerol derivatives allow spin dilution. 
A

C

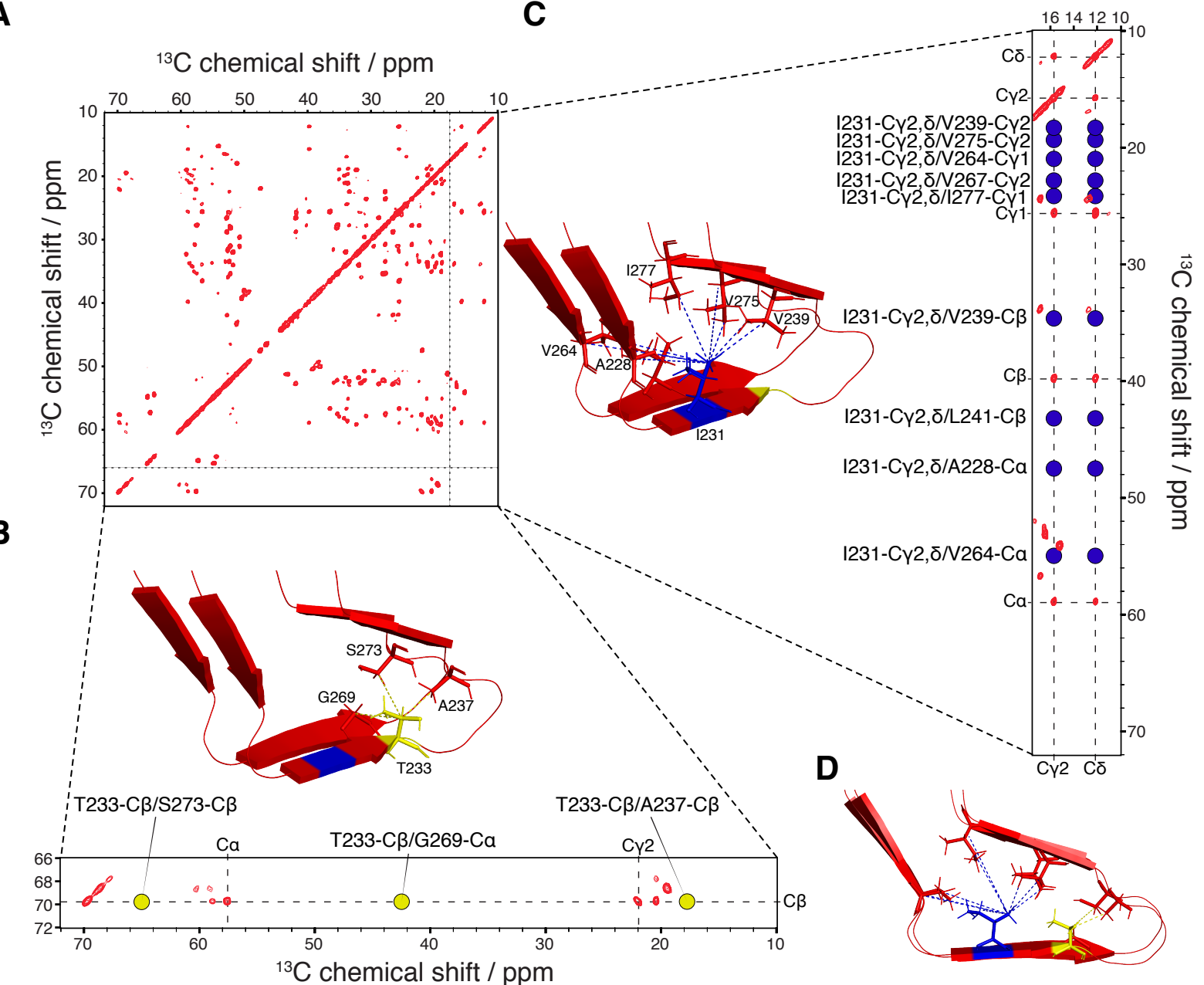

Fig.4: Illustration of long range through-space distance determination, based on HET-s(218-289) amyloid core [43].

A $2 \mathrm{D}-{ }^{13} \mathrm{C}-{ }^{13} \mathrm{C}$ PDSD spectrum (50ms mixing time) of HET-s(218-289) uniformly labelled $\left({ }^{13} \mathrm{C} /{ }^{15} \mathrm{~N}\right)$ recorded on a $800 \mathrm{MHz}$ spectrometer (proton frequency). B Excerpts of the PDSD spectrum shown in A, displaying only threonine correlations. T233 resonances are highlighted with dashes $(\mathrm{C} \alpha, \mathrm{C} \beta, \mathrm{C} \gamma 2)$. Reported distances regarding T233 are displayed with yellow dots and illustrated on the HET-s(218-289) structure (PDB ID: 2RNM). C Excerpts of the PDSD spectrum shown in A, (ppm window: 10-17.5). I231 resonances are highlighted with dashes $(C \alpha, C \beta, C \gamma 1, C \gamma 2, C \delta)$. Reported distances regarding I231 are displayed with blue dots and illustrated in HET-s(218-389) structure (PDB ID: 2RNM). For clarity purposes, overlapping peaks were disregarded. D HET-s structure [43], as shown in B-C, from a lateral point of view. All mentioned distances were determined based on either PDSD long-mixing time experiments (with $\left[2-{ }^{13} \mathrm{C}\right]$ - or $\left[1,3-{ }^{13} \mathrm{C}_{2}\right]$-glycerol labelling schemes), or CHHC spectra (with a fully labelled HET-s amyloid core sample). 


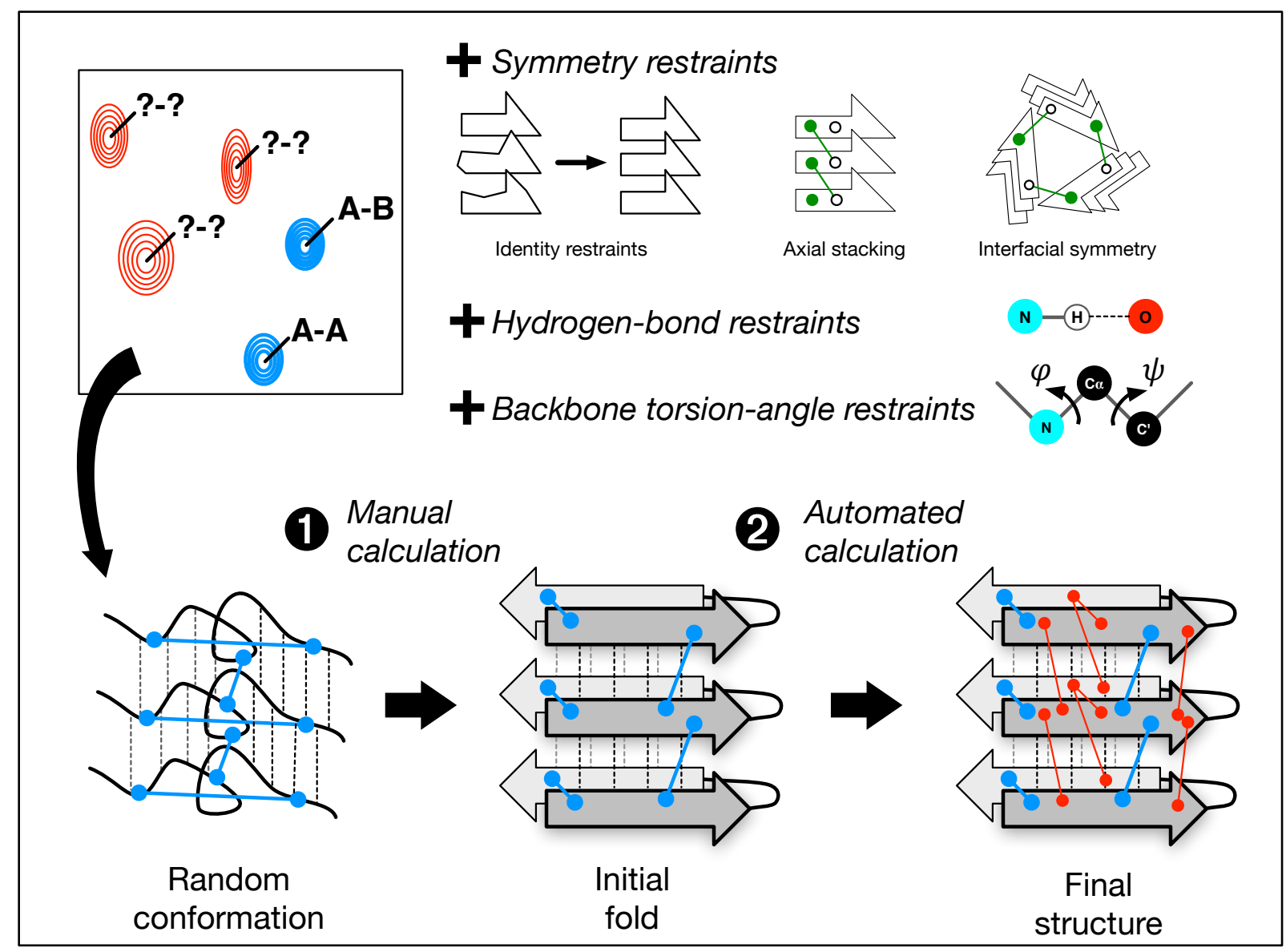

Fig.5: General procedure for 3D structure calculation of amyloid fibrils structures from ssNMR.

First, distance restraints derived from unambiguously assigned cross-peaks or peaks with low spectral ambiguity are used for structural calculation to established the initial fold of the fibrils (Manual calculation). Next, the restraint set is supplemented with all identified cross-peaks (generally with high spectral ambiguity) that will be assigned automatically and yielding a high precision bundle of conformers as the final structure (Automated calculation). Owing to the highly-ordered nature of amyloid fibrils, symmetry restraints are employed to ensure a symmetric arrangement of subunits during calculation (identity restraints, axial stacking and interfacial symmetry, if applicable). Additionally, backbone dihedral angle restraints, derived for secondary chemical shifts, and distance restraints enforcing hydrogen-bonds are implemented in order to impose a regular conformation and proper stacking of stands. 